\title{
Achyranthes aspera Root Extracts Induce Human Colon Cancer Cell (COLO-205) Death by Triggering the Mitochondrial Apoptosis Pathway and S Phase Cell Cycle Arrest
}

\author{
Shagun Arora and Simran Tandon \\ Department of Biotechnology and Bioinformatics, Jaypee University of Information Technology, Waknaghat, Solan, \\ Himachal Pradesh 173234, India
}

Correspondence should be addressed to Simran Tandon; simran.tandon@juit.ac.in

Received 23 July 2014; Accepted 28 August 2014; Published 27 October 2014

Academic Editor: David E. Misek

Copyright (C) 2014 S. Arora and S. Tandon. This is an open access article distributed under the Creative Commons Attribution License, which permits unrestricted use, distribution, and reproduction in any medium, provided the original work is properly cited.

\begin{abstract}
Achyranthes aspera (AA) has been used traditionally for the cure of various disorders. However, the action of root extracts of AA as anticancer agent and its cellular mechanism remain unclear. The aim was to screen the antitumor effect of ethanolic (EAA) and aqueous (AAA) root extracts on the growth of colon cancer COLO-205 cells by testing their cytotoxicity, followed by their effect on clonogenicity, migration, and induction of apoptosis. Mechanisms leading to apoptosis and cell cycle arrest were also investigated by expression studies of caspase-9, caspase-3, Bax, Bcl-2, p16, p21, and p27 genes, followed by flow cytometric analysis for cell cycle distribution. Cytotoxicity screening of AA extracts indicated greater cytotoxic activity of AAA extract against COLO-205 cells. A series of events marked by apoptosis revealed loss of cell viability, chromatin condensation, and DNA fragmentation in AAA treated cells to a greater extent. The mRNA expression levels of caspase-9, caspase-3, Bax, p16, p21, and p27 were markedly increased in the AAA treated cells, along with decreased Bcl-2 expression. The cell cycle arrest at $\mathrm{S}$ phase was detected by flow cytometric analysis after treatment with AAA. Overall the study signifies the aqueous extracts as a promising therapeutic candidate against cancer.
\end{abstract}

\section{Introduction}

Despite significant advances toward targeted therapy and screening techniques, colon cancer continues to be a chronic disease worldwide, being the third leading cause of death in men and the second in women globally. According to the Globocan 2012 Cancer Fact Sheet, about 1.36 million new cases of colon cancer were clinically diagnosed, with number of deaths being 0.69 million [1]. In the development of cancer, evasion of apoptosis is one of the major factors resulting in overpopulation of cancer cells. Apoptosis is an active form of cell death guided by a set of prosurvival and antisurvival genes [2]. There is a strong corelation between loss of apoptotic control and cancer initiation and progression, as tumor cells lose their ability to activate the death signalling pathway [3]. Other than apoptosis, deregulated cell-cycle control is a key feature of cancer progression. In normal cells, the cell cycle begins or stops only in response to proliferationenhancing or retarding signals, respectively, which however is not seen in cancer cells. As a result of this, their proliferation remains unchecked [4].

Although conventional chemotherapeutic drugs induce cell death, they are limited by their toxicity to normal cells. Identification of natural agents in form of either plant extracts or a bioactive compound, which successfully exhibits apoptotic and cell cycle modulating properties and at the same time shows limited toxicity to normal cells, is therefore essential [5].

Any health care practices, which do not form a part of conventional western medicine, are referred to as complementary and alternate therapies (CAM). According to WHO, $80 \%$ of the world's population relies upon the use of traditional herbal medicines for general wellness [6]. An effective strategy for identifying potential anticancer molecules should 
be based upon validation of those plants whose ethnobotanical and ethnopharmacological use have shown promise rather than mass screening of plants in general. The use of herbs, plants, and homeopathic, Ayurvedic, and traditional medicines has been outlined as a part of CAM therapies from ancient times; however the effectiveness of such therapies against cancer management and prevention is still uncertain due to either lack of scientific data or safety related issues. An understanding of the use of CAM therapies in mainstream cancer treatment therefore is the need of the hour. Achyranthes aspera (AA) is a known traditional herb, which belongs to family Amaranthaceae. All parts of AA are used in traditional system of medicines such as seeds, roots, and shoots. AA is used for the management of various diseases such as malaria, dysentery, sinuses, asthma, piles, night blindness, hypertension, and diabetes [7]. The leaf extracts of AA have shown antioxidant, diuretic, antidepressant, hepatoprotective, wound-healing, and cancer chemopreventive effects [811]. Other than leaves, roots of AA possess anti-inflammatory and immunomodulatory effects $[12,13]$. Although the use of AA which started in the Vedic period continues to be a part of present era, the experimental studies into the effective role of roots of Achyranthes aspera against colon cancer management and its mechanism of action are still limited.

Therefore, the aims of this study were the following: (1) to evaluate the cytotoxic activities of the AA root extracts against COLO-205 cells and (2) to further investigate the molecular mechanism of apoptosis triggered by the best extract.

\section{Materials and Methods}

2.1. Sample Collection. The dried roots of AA were procured from Natural Remedies Pvt. Ltd. at Bangalore, India. The voucher specimen is available at Natural Remedies.

\subsection{Preparation of Extracts}

2.2.1. Preparation of Ethanolic Extract of Achyranthes aspera Roots (EAA). 10 grams of dried roots was ground to a powder and suspended in $100 \mathrm{~mL}$ of $70 \%$ ethanol at room temperature overnight to prepare $10 \%(\mathrm{w} / \mathrm{v})$ extract. The supernatant was filtered by Whatman filter number 2 . The filtrate obtained was further concentrated in rotary evaporator (at $50^{\circ}-60^{\circ} \mathrm{C}$ ) under reduced pressure leaving a dark brown residue. The EAA thus obtained was transferred to a Petri dish and kept in an oven $\left(50^{\circ} \mathrm{C}\right)$ until the solvent was completely evaporated. The average yield was $8 \%$. It was stored in air tight container at $-20^{\circ} \mathrm{C}$ till further use.

2.2.2. Preparation of Aqueous Extract of Achyranthes aspera Roots ( $A A A)$. 10 grams of dried roots which had been ground to a powder was suspended in $100 \mathrm{~mL}$ of water at room temperature overnight to prepare $10 \%(\mathrm{w} / \mathrm{v})$ extract. The supernatant was filtered by Whatman filter number 2 . The filtrate was then lyophilized and the average yield was $12 \%$. The powder was stored at $-20^{\circ} \mathrm{C}$ till further use.
For the cell culture based assays, $100 \mathrm{mg} / \mathrm{mL}$ stock solutions were prepared by dissolving extracts in DMSO and filtered through 0.22 micron filters and stored at $-20^{\circ} \mathrm{C}$ till further use. The stocks were diluted in cell culture media at the appropriate concentrations, prior to addition to cells.

2.3. Cell Culture. COLO-205 cells were obtained from NCCS, Pune, India. The cells were cultured in RPMI media supplemented with $1 \%$ antibiotic (penicillin-streptomycin), 10\% FBS, and $1 \%$ sodium pyruvate. All the chemicals used for cell culture were obtained from Sigma-Aldrich, India. The cells were maintained at $37^{\circ} \mathrm{C}$ in a $5 \% \mathrm{CO}_{2}$ incubator.

2.4. Determination of Total Phenolic Content. The total phenolic content (TPC) was determined using Folin-Ciocalteu reagent. To $50 \mu \mathrm{L}$ of AA root extracts, $3.5 \mathrm{~mL}$ of water and $250 \mu \mathrm{L}$ FC ( $2 \mathrm{~N}$ Folin-Ciocalteu) reagent were added. The solution was mixed and incubated for 8 minutes at room temperature. To this, $750 \mu \mathrm{L}$ of $20 \%$ sodium carbonate solution was added and incubated for another $2 \mathrm{hrs}$ at room temperature. At the end of incubation, the absorbance was taken at $765 \mathrm{~nm}$. The TPC value was expressed as $\mu \mathrm{g}$ gallic acid equivalents (GAE)/gram of dry extract [14].

\subsection{Determination of Antioxidant Activity}

2.5.1. DPPH Assay. Free radical scavenging activity was calculated using DPPH (1, 1 diphenyl-2-picrylhydrazyl) assay [14]. To $1.5 \mathrm{~mL}$ of AA root extracts of varying concentrations, $1.5 \mathrm{ml}$ of $0.135 \mathrm{mM}$ DPPH solution was added and incubated in the dark at room temperature for 30 minutes. The absorbance of the mixture was measured at $517 \mathrm{~nm}$. The $\mathrm{IC}_{50}$ values were obtained and referred to as the concentration $(\mu \mathrm{g} / \mathrm{mL})$ of extract that scavenges the DPPH radicals by $50 \%$.

The calculations were as follows:

DPPH radical scavenging activity (\%)

$$
=\left[\frac{A_{\text {control }}-A_{\text {test }}}{A_{\text {control }}}\right] \times 100 \text {, }
$$

where $A_{\text {control }}$ : absorbance of DPPH radical + methanol and $A_{\text {test }}$ : absorbance of DPPH radical + sample extract.

2.5.2. FRAP Assay. The antioxidant activity was also evaluated by estimating the FRAP (ferric reducing ability of plasma) value. To $150 \mu \mathrm{L}$ of AA root extracts, $2850 \mu \mathrm{L}$ of FRAP solution was added and incubated for 30 minutes in the dark. Readings of the coloured product (ferrous tripyridyltriazine complex) were taken at $593 \mathrm{~nm}$. Higher FRAP value indicates higher antioxidant potential. The results were expressed in $\mu \mathrm{M}$ Fe (II)/gram of dry extract [14].

2.6. Trypan Blue Viability Assay. The dye exclusion assay was used to determine the number of viable cells present in a cell suspension. $10^{5}$ cells $/ \mathrm{mL}$ was seeded in a 12 -well plate and treated with different concentration of EAA and AAA $(50-200 \mu \mathrm{g} / \mathrm{mL})$ for either 48 or 72 hours. After treatment, 


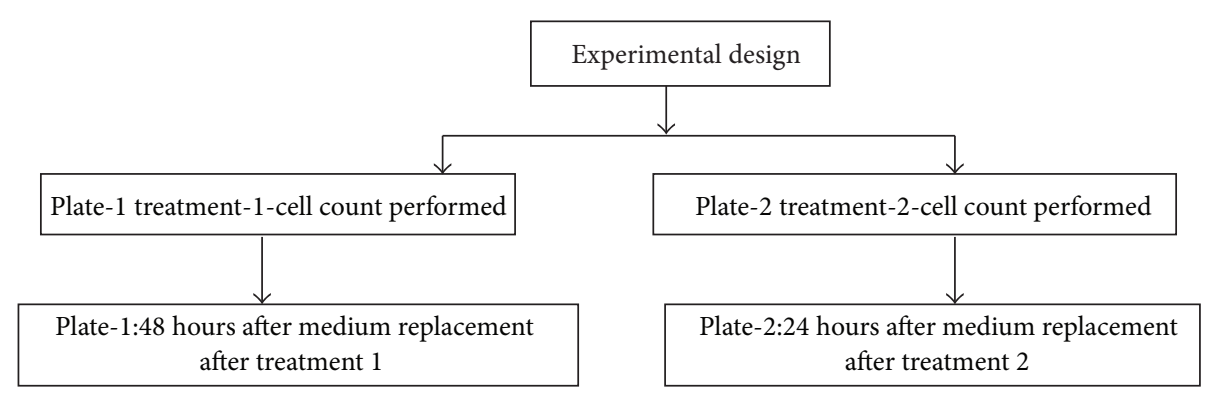

FIGURE 1: The work plan for carrying out antiproliferative assay of EAA and AAA treated cells on COLO-205 cells.

the cells were trypsinized and counted by a haemocytometer [15]. Cell viability was determined by following formula:

$$
\% \text { Viability }=\frac{\text { Number of viable cells counted }}{\text { Total number of cells counted }} \times 100 \text {. }
$$

2.7. Cytotoxicity Assay by MTT Assay. The cytotoxic activity was measured using MTT (3-(4, 5 dimethylthiazol-2-yl)-2, 5diphenyl tetrazolium bromide) assay [15]. This colorimetric assay measures the reduction of yellow MTT to an insoluble, coloured (dark purple) formazan product by mitochondrial succinate dehydrogenase. Briefly, $10^{4}$ cells/well were seeded in 96-well microplates. Cells were treated with various concentrations of EAA and AAA (50-200 $\mu \mathrm{g} / \mathrm{mL})$ for 72 hours. 5 -FU $(1-5 \mu \mathrm{g} / \mathrm{mL})$ was used as the positive control. At the end of treatment, $15 \mu \mathrm{L}$ of MTT $(5 \mathrm{mg} / \mathrm{mL})$ was added to each well and incubated for another 4 hours. The formazan products were solubilized by adding $130 \mu \mathrm{L}$ of DMSO. The optical density was measured at $570 \mathrm{~nm}$ using a microplate reader. The percent cell cytotoxicity was calculated by means of the following formula:

$$
\% \text { Cell cytotoxicity }=100-\left\{\frac{A_{\text {control }}-A_{\text {test }}}{A_{\text {control }}} \times 100\right\} .
$$

The $\mathrm{IC}_{50}$ values for both EAA and AAA were determined by plotting a dose response curve and from the generated straight line equation the concentrations which lead to $50 \%$ inhibition were obtained.

2.8. Assessment of Growth Kinetics. To evaluate whether the extracts had any growth retarding effects, the change in growth kinetics was determined by treating cells with $\mathrm{IC}_{50}$ of EAA $(184.1 \pm 1.8 \mu \mathrm{g} / \mathrm{mL})$ and AAA $(165.7 \pm 0.6 \mu \mathrm{g} / \mathrm{mL})$ for 72 hours. Later the change in cell growth was observed under phase contrast microscope at 100x magnification using Nikon eclipse Ti microscope [16].

2.9. In Vitro Wound Scratch Assay. To confirm the migration capability of the COLO-205-treated cells, the scratch motility assay was carried out [17]. $10^{5}$ cells/well were seeded into a 12-well plate and were allowed to grow overnight to reach confluency. The monolayer was then scratched using a $20-200 \mu \mathrm{L}$ micropipette tip, washed with PBS twice to remove detached cells, and photographed at 0 hours. The cells were then treated with $\mathrm{IC}_{50}$ values of EAA (184.1 \pm $1.8 \mu \mathrm{g} / \mathrm{mL})$ and AAA $(165.7 \pm 0.6 \mu \mathrm{g} / \mathrm{mL})$ for 24 hours. After incubation period of 24 hours, the cells which migrated into the scratched area were photographed under a phase-contrast inverted microscope at a magnification of 40x (Nikon eclipse $\mathrm{Ti})$.

2.10. Clonogenic Survival Assay. Clonogenic survival assay was performed to investigate the antiproliferation capabilities of AA extracts [18]. Briefly, 5000 cells $/ \mathrm{mL}$ were seeded in a 6well plate and after achieving $80 \%$ confluence the cells were treated with EAA $(184.1 \pm 1.8 \mu \mathrm{g} / \mathrm{mL})$ and AAA $(165.7 \pm$ $0.6 \mu \mathrm{g} / \mathrm{mL}$ ) at their $\mathrm{IC}_{50}$ for 72 hours. The old media were removed and replaced with fresh complete medium and kept for another 10 days. After 14 days of incubation, the colonies were fixed with $4 \%$ paraformaldehyde at room temperature for 20 minutes and stained with $0.1 \%$ crystal violet for 10 minutes and, finally, positive colony formation $(<50$ cells/colony) was counted using a colony counter (DECIBEL, Digital Technologies, magnification $\times 1.74$ ) and percent colony formation was calculated.

2.11. Antiproliferation Assay. To compare the rate of cell proliferation in presence or absence of AA root extracts after specific treatment, we modified the cell viability method [15]. $0.5 \times 10^{5}$ cells $/ \mathrm{mL}$ were seeded in a 24 -well plate and treated with different concentration of EAA and AAA (50$200 \mu \mathrm{g} / \mathrm{mL}$ ) for 48 and 72 hours. At the end of treatment, one set of cells was assayed for cell viability using trypan blue. In other sets, the old medium containing the AA extracts was replaced with fresh medium (minus extract) and incubated for a specified period, prior to growth assay. On completion of treatment, the cell count was performed. A schematic representation of the assay is depicted in Figure 1. The rationale for performing this assay was to ascertain whether the growth retarding effects were reversible, in which case the cell count would increase, or irreversible, wherein the cell count would decrease as the extracts would have had affected the cells in a permanent manner.

\subsection{Induction of Apoptosis}

2.12.1. Hoechst Staining. A cell undergoing apoptosis displays the signs of nuclear condensation and DNA fragmentation 
which can be visualised by staining with Hoechst 33258 dye. In a 12 -well plate, the cells $\left(10^{5}\right.$ cells $\left./ \mathrm{mL}\right)$ were cultured in the presence or absence of EAA $(184.1 \pm 1.8 \mu \mathrm{g} / \mathrm{mL})$ or AAA $(165.7 \pm 0.6 \mu \mathrm{g} / \mathrm{mL})$ at its $\mathrm{IC}_{50}$ for 72 hours. At the end, cells were fixed with $4 \%$ of paraformaldehyde for 30 minutes at $4^{\circ} \mathrm{C}$ and permeabilized with $0.1 \%$ Triton X-100 for 15 minutes. Finally, the cells were stained with $5 \mu \mathrm{g} / \mathrm{mL}$ of Hoechst 33258 dye for 10 minutes at room temperature and visualized and photographed at 100x magnification using Nikon eclipse $\mathrm{Ti}$ fluorescence microscope. Nuclei that showed bright blue fluorescence with condensed or fragmented DNA were considered as apoptotic cells, while normal cells appeared to be blue in colour with compact structure [19].

2.12.2. Acridine Orange/Ethidium Bromide Staining. Acridine orange/ethidium bromide $(\mathrm{AO} / \mathrm{EB})$ staining is used to determine the nuclear changes associated with apoptosis. In a 12 -well plate, the cells $\left(10^{5}\right.$ cells $\left./ \mathrm{mL}\right)$ were cultured in the presence or absence of EAA $(184.1 \pm 1.8 \mu \mathrm{g} / \mathrm{mL})$ or AAA $(165.7 \pm 0.6 \mu \mathrm{g} / \mathrm{mL})$ at its $\mathrm{IC}_{50}$ for 72 hours. Later, both adherent and cells in suspension were collected and centrifuged at $130 \mathrm{~g}$ for 5 minutes. The pellet was resuspended in a solution of $25 \mu \mathrm{L}$ PBS and $2 \mu \mathrm{L} \mathrm{EB} / \mathrm{AO}$ dye $(100 \mu \mathrm{g} / \mathrm{mL})$. Slides were prepared and fluorescence was observed with the help of a Nikon eclipse Ti fluorescence microscope at 200x magnification [20]. AO is a cell-permeant DNA dye that stains both live and dead cells, while EB is cell-impermeant DNA dye that stains only cells with lost membrane integrity. On staining, live cells give green colour with intact membrane and early apoptotic cells display bright green dots in the nuclei as a consequence of chromatin condensation and nuclear fragmentation.

2.12.3. Annexin V/Propidium Iodide (PI) Staining. The annexin V/PI staining is used to discriminate between apoptotic and viable cells. Apoptotic cells are stained positively for annexin $\mathrm{V}$ that binds to phosphatidylserine (PS) but are negative for staining with PI, whereas viable cells are negative for both annexin V and PI staining. $10^{5}$ cells were seeded into each well of a 12-well plate; next day EAA and AAA at its $\mathrm{IC}_{50}$ value were added for 72 hours. The subsequent procedures were carried out according to the instructions provided by the manufacturer of ApoDETECTTM Annexin V-FITC Kit as follows, at the end of treatment cells in both monolayer and suspension were collected and centrifuged at $3000 \mathrm{rpm}$ for 1 minute. The supernatant was decanted and the cells washed with $1 x$ PBS and centrifuged at $3000 \mathrm{rpm}$ for 1 minute. The pellet was resuspended in $190 \mu \mathrm{L}$ of annexin binding buffer and $10 \mu \mathrm{L}$ of annexin $\mathrm{V}$ dye $(20 \mu \mathrm{g} / \mathrm{mL})$ was added, mixed gently, and incubated for 10 minutes at room temperature. The cells were then washed and resuspended in $190 \mu \mathrm{L}$ of binding buffer and $10 \mu \mathrm{L}$ of propidium iodide dye $(20 \mu \mathrm{g} / \mathrm{mL})$. Finally, imaging of the apoptotic cells under Nikon fluorescent microscope was done and photographed at 100x [21].

2.12.4. DNA Fragmentation Assay by Agarose Gel Electrophoresis. The endonuclease-mediated cleavage by CAP (caspase activated proteases) enzymes of nuclear DNA leads to formation of DNA fragments of specific size of 180-200 bp, which is one of the evidences of apoptosis. To confirm the apoptotic effect, $10^{6}$ cells were seeded in a $35 \mathrm{~mm}$ dish and treated in presence or absence of EAA and AAA at its $\mathrm{IC}_{50}$ value for 72 hours. The protocol for DNA fragmentation assay was as follows: at the end of incubation period, both the cells in suspension and attached cells were pooled together in $1.5 \mathrm{~mL}$ Eppendorf vial and centrifuged at $200 \mathrm{~g}$ for 10 minutes at $4^{\circ} \mathrm{C}$. The pellet was resuspended with $0.5 \mathrm{ml}$ TTE $(10 \mathrm{mM}$ Tris-Hcl $+1 \mathrm{mM}$ EDTA $+0.2 \%$ Triton-X 100) and vortexed vigorously. The vials were centrifuged at 20,000 g for 10 minutes at $4^{\circ} \mathrm{C}$ and the supernatant was collected in a new vial. $0.1 \mathrm{~mL}$ icecold $5 \mathrm{M} \mathrm{NaCl}$ and $0.7 \mathrm{~mL}$ ice-cold isopropanol were added and vortexed vigorously, followed by overnight incubation at $-20^{\circ} \mathrm{C}$ to allow DNA to precipitate.

Next day, the vials were centrifuged at 20,000 $\mathrm{g}$ for 10 minutes at $4^{\circ} \mathrm{C}$ and washed with $0.5-0.7 \mathrm{~mL}$ ice-cold $70 \%$ ethanol by centrifuging at $16,000 \mathrm{~g}$ for 10 minutes at $4^{\circ} \mathrm{C}$. Finally, the pellet was dissolved in $50 \mu \mathrm{L}$ TE (Tris-Hcl-EDTA). The DNA samples were run on a $1 \%$ agarose gel containing ethidium bromide and visualised using a BioRad Gel-Doc system [22].

2.12.5. Quantitative Analysis for DNA Fragmentation. The amount of DNA fragmentation in cancer cells was quantified using diphenylamine method. This method is based on the principle that extensively fragmented double-stranded DNA can be prepared from chromosomal DNA upon centrifugal sedimentation and colorimetrically quantified upon reaction with diphenylamine (DPA), which binds to deoxyribose [22]. $10^{6}$ cells were seeded in $35 \mathrm{~mm}$ dish and treated in presence or absence of EAA and AAA at its $\mathrm{IC}_{50}$ values for 72 hours. At the end, $0.5 \mathrm{~mL}$ ice-cold extraction buffer $(10 \mathrm{mM}$ Tris$\mathrm{Hcl}, \mathrm{pH} 7.5$, containing $1 \mathrm{mM}$ EDTA and $0.2 \%$ Triton $\mathrm{X}-100$ ) was added to cells and centrifuged at $13000 \mathrm{~g}$ for 10 minutes at $4^{\circ} \mathrm{C}$ (tube $\mathrm{B}$ ). The supernatant was transferred to new vial (tube A) and $0.5 \mathrm{~mL}$ of extraction buffer was added to tube $\mathrm{B}$ and $0.5 \mathrm{~mL}$ of $25 \%$ trichloroacetic acid (TCA) to both tubes $\mathrm{A}$ and $\mathrm{B}$ and vortexed vigorously. The tubes were kept at $4^{\circ} \mathrm{C}$ for overnight incubation. Next morning, the supernatant was centrifuged for 10 minutes at $13000 \times \mathrm{g}$ and aspirated followed by the addition of $80 \mu \mathrm{L}$ of $5 \%$ TCA to each pellet and the DNA was hydrolyzed by heating for 20 minutes at $83^{\circ} \mathrm{C}$ in a water bath. Finally, $160 \mu \mathrm{L}$ of diphenylamine solution was added to each vial. All the tubes were vortexed and then left overnight at room temperature and took the absorbance at $620 \mathrm{~nm}$. The percentage of fragmented DNA was calculated by means of following formula:

$$
\% \text { fragmented DNA }=\frac{\text { O.D tube } A}{\text { O.D tube } A+\text { O.D tube } B} \times 100 \text {. }
$$

2.13. Gut Bacterial Hydrolysis. Cytotoxic assessment of plant extracts does not take into account that the naturally occurring compounds may not be active by themselves but may require certain modifications within the parent compound to obtain active molecules which can then act within the body. 
Thus, a cytotoxicity assay with a prior enzymatic hydrolysis procedure was followed in this study using $\beta$-glucosidase, an enzyme found not only in bacterial gut flora but also in human body [23]. Briefly, $10^{4}$ cells/well were seeded in 96well plate and treated with various concentrations of AAA with and without $\beta$-glucosidase enzyme treatment for 72 hours. Following this, SRB assay was conducted and percent cytotoxicity calculated using following formula:

$\%$ cell cytotoxicity

$$
=100-\left\{\frac{\text { Number of viable cells }}{\text { Total number of cells }} \times 100\right\} .
$$

2.14. Gene Expression Studies. In order to evaluate the effects of the AAA extract on the expression of key genes involved in the apoptotic pathway, the total cellular RNA was isolated from the untreated and AAA treated cells $(165.7 \pm 0.6 \mu \mathrm{g} / \mathrm{mL})$ using Trizol reagent according to manufacturer's protocol. The integrity and purity of RNA were electrophoretically verified by formaldehyde agarose gel stained with ethidium bromide and the O. $D_{260 \mathrm{~nm}} / \mathrm{O}_{2} \mathrm{D}_{280 \mathrm{~nm}}$ ratio was quantified using nanodrop. One microgram $(1 \mu \mathrm{g})$ of RNA was reverse transcribed into cDNA in a reverse transcription reaction mixture containing $1 \mathrm{x}$ PCR buffer, $0.5 \mathrm{mM}$ deoxynucleoside triphosphates (dNTPs), $2.5 \mu \mathrm{M}$ of oligo d (T) primer, and 2.5 units of MuLV reverse transcriptase [24]. The reaction mixture was incubated at $46^{\circ} \mathrm{C}$ for 1 hour. The synthesised cDNA was quantified using nanodrop and equal amount of cDNA was used in the present study to quantify the amount of change in expression of cancer cells after treatment. PCR reactions was carried out in a final volume of $20 \mu \mathrm{L}$ containing $12.5 \mu \mathrm{L}$ of PCR green mix (Fermentas), $1 \mu \mathrm{g}$ cDNA, $1 \mu \mathrm{L}$ of forward and reverse primer ( $1 \mathrm{mM}$ of each primer), and $4.5 \mu \mathrm{L}$ of nuclease free water. The PCR products were run on $1.8 \%$ agarose gel using ethidium bromide, and densitometry scanning of the bands was done using an Alpha Innotech Gel Doc using the Alpha imager EP software. The values for each gene product were normalised to the house-keeping gene, $\beta$-actin. The primer sequences of the genes included in our study are shown in Table S1 in Supplementary Material available online at http://dx.doi.org/10.1155/2014/129697 [2528].

2.15. Cell Cycle Analysis by Flow Cytometry. If any treatment results in the slowing down of the cell cycle, then the number of cells in the various phases of the cell cycle would vary from that of the control cells. To check the effect of AAA on cell cycle distribution of COLO-205 cells, flow cytometric analysis by PI staining was performed. PI is a highly water soluble, fluorescent dye that binds to DNA by intercalating between the bases in double stranded nucleic acids of exposed nuclei. The relative fluorescence intensity of PI is an indirect measure of the cellular DNA content [29]. $2 \times 10^{6}$ cells were seeded in a $60 \mathrm{~mm}$ dish and treated with $\mathrm{IC}_{50}$ value of AAA $(165.7 \pm 0.6 \mu \mathrm{g} / \mathrm{mL})$ for 72 hours. Later, cells in suspension along with monolayer cells which were detached by trypsinization and were pooled and centrifuged at $300 \mathrm{~g}$ for 5 minutes. To the pellet, we added $0.5 \mathrm{~mL}$ of PBS and fixed the cells by transferring $4.5 \mathrm{~mL}$ of $70 \%$ ethanol to cell suspension (added in a dropwise manner) for at least 2 hours at $-20^{\circ} \mathrm{C}$. The cell solution was then centrifuged at $300 \mathrm{~g}$ for 5 minutes and the pellet was resuspended in $1 \mathrm{~mL}$ of PBS and stained with $1 \mathrm{~mL}$ of PI staining solution $(100 \mu \mathrm{g} / \mathrm{mL}$ RNAase, $50 \mu \mathrm{g} / \mathrm{mL}$ propidium iodide, and $0.5 \%$ Triton-X 100 in PBS) for 30 minutes at room temperature in the dark. Samples were analyzed using BD AccuriR C6 Flow Cytometer in the FL2 channel (laser $488 \mathrm{~nm}$ and filter $485 / 40 \mathrm{~nm}$ ). 10,000 events per sample were recorded for each experiment.

2.16. GC-MS Analysis. GC-MS analysis was carried out using thermo GC model TRACE 1300 and thermo MS model TSQ 8000 (triple quadrapole) equipment employing the following conditions: Thermo TG 5 MS Column having dimensions of "30 $\times 0.25 \mathrm{~mm} \times 0.25 \mu \mathrm{m}$ ", operating in electron impact mode at $70 \mathrm{eV}$. Helium (99.999\%) was used as carrier gas at a constant flow rate of $1 \mathrm{~mL}$ per minute and an injection volume of $1 \mu \mathrm{L}$. An injector temperature of $250^{\circ} \mathrm{C}$ and an ion-source temperature of $280^{\circ} \mathrm{C}$ were employed. The Oven program consisted of maintaining the temperature at $60^{\circ} \mathrm{C}$ for 2 minutes followed by an increase to $250^{\circ} \mathrm{C}$ at the rate of $15^{\circ} \mathrm{C} /$ minute and maintaining this temperature of $250^{\circ} \mathrm{C}$ for a further 15 minutes. The percentage of each chemical constituent was calculated by comparing the average peak area to the total areas.

2.17. Statistical Analysis. All experiments were performed thrice in triplicate and the data was presented as mean \pm SD. Statistical analysis was conducted with the GraphPad InStat software. One way ANOVA was used to compare untreated cells with treated cells in case of in vitro studies. A minimum $P$ value $<0.05$ was considered to indicate a statistically significant difference.

\section{Results}

3.1. Total Phenolic Content. The results showed that EAA contained greater amounts of phenolic compounds with a TPC value of $419.2 \pm 1.3 \mu \mathrm{g}$ GAE/gram of dry extract as compared to AAA having $273.8 \pm 2.5 \mu \mathrm{g}$ GAE/gram of dry extract of total phenolic content.

3.2. In Vitro Antioxidant Activity. The capacity of an extract to scavenge free radical formation was examined by performing two different assays, that is, FRAP and DPPH assay. The results showed EAA to exhibit greater antioxidant activity with a FRAP value of $195 \pm 1.2 \mu \mathrm{M} \mathrm{Fe}$ (II)/gram of dry extract and $\mathrm{IC}_{50}$ value of DPPH radical of $288.3 \pm 1.4 \mu \mathrm{g} / \mathrm{mL}$ of dry extract as compared to AAA with FRAP value of $121 \pm 1.5$ and $\mathrm{IC}_{50}$ value of DPPH radical $372.6 \pm 1.7$. A positive corelation was found between TPC and antioxidant activity in both extracts with an $R^{2}$ value of 0.998 .

3.3. Cell Viability Assay. Live cells have intact cell membrane that excludes trypan blue dye, whereas dead cells do not. As clearly evident in Figure S1, AA treatment of COLO-205 cells leads to a dose and time dependent decrease in cell viability 


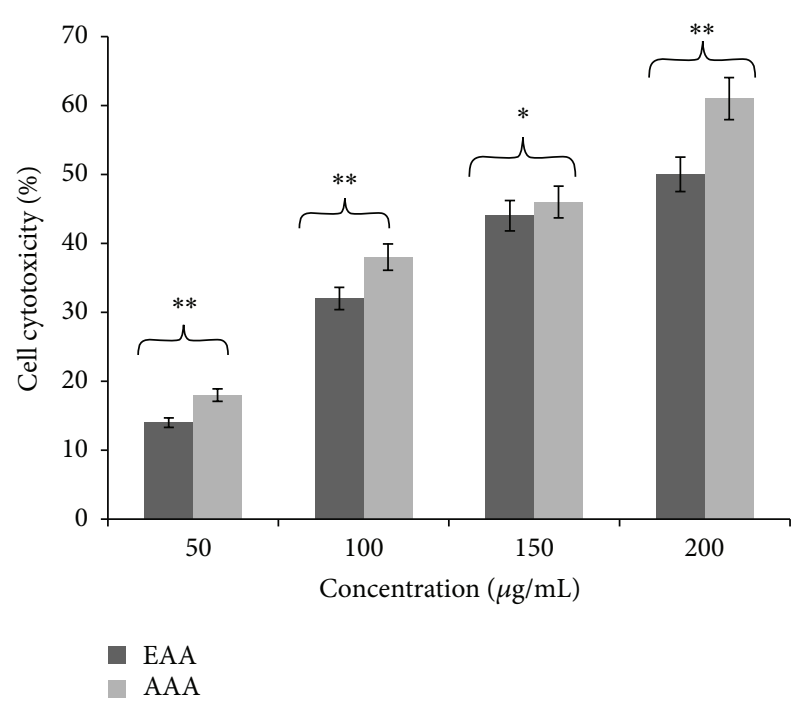

FIgURE 2: Dose dependent cytotoxic effect of AA extracts on COLO-205 cells by MTT assay. Cells were incubated with various concentrations of AA extracts $(50,100,150$, and $200 \mu \mathrm{g} / \mathrm{mL})$ for 72 hours. Data presented as mean $\pm \mathrm{SD}(n=3)$ and compared as percent cytotoxicity of EAA versus percent cytotoxicity of AAA. ${ }^{*} P<0.05 ;{ }^{* *} P<0.01$.

as compared to the untreated controls. Figure S1 A represents the percent viability of EAA treated COLO-205 cells which decreased to $35.49 \pm 1.1(P<0.01)$ and $25.34 \pm 0.8(P<$ $0.001)$ at 48 and 72 hours of treatment, respectively, at a dose of $200 \mu \mathrm{g} / \mathrm{mL}$. A similar trend was observed but was more pronounced in the AAA treated COLO-205 cells as is seen in Figure S1 B with percent viability decreasing to $19.01 \pm 0.2$ $(P<0.0001)$ at 72 hours and $30.45 \pm 0.6(P<0.001)$ at 48 hours. Since we observed more marked effects at 72 hours of treatment, subsequent experiments were performed at this time period.

3.4. Cell Cytotoxicity by MTT Assay. In Figure 2, the percent cell cytotoxicity of EAA and AAA towards COLO-205 cells revealed that AAA was relatively more cytotoxic towards COLO-205 cells as evidenced from the lower $\mathrm{IC}_{50}$ of $165.7 \pm$ $0.6 \mu \mathrm{g} / \mathrm{mL}$ which was the concentration that caused $50 \%$ loss of cell viability, as compared to EAA with an $\mathrm{IC}_{50}$ of $184.1 \pm$ $1.8 \mu \mathrm{g} / \mathrm{mL}$. The $\mathrm{IC}_{50}$ of each of the AA root extracts against COLO-205 cells was used as the effective dose for our next set of experiments.

3.5. Assessment of Growth Kinetics. Exponentially growing cells, when treated with $\mathrm{IC}_{50}$ of EAA $(184.1 \pm 1.8 \mu \mathrm{g} / \mathrm{mL})$ and AAA $(165.7 \pm 0.6 \mu \mathrm{g} / \mathrm{mL})$ for 72 hours, showed marked regression in growth, which was evident when viewed under a phase contrast microscope. The loss of cellular attachment to the substratum and increase in number of floating cells seen in the cell culture wells were indicators of cell death and revealed altered growth kinetics in treated cells. Figure 3(a) showed the normal confluence of untreated control culture of COLO-205 cells at 72 hours with no apparent signs of cell death, while after treatment marked decrease in cell number was evident owing to cell death (Figures 3(b) and 3(c)) and this effect was more pronounced after AAA treatment indicating enhanced growth inhibitory effects of AAA towards COLO-205 cells in contrast to EAA.

3.6. In Vitro Wound Scratch Assay. The ability of EAA and AAA to inhibit cell motility was investigated by in vitro scratch assay. A denuded area was created and cells were exposed to the $\mathrm{IC}_{50}$ concentration of AAA $(165.7 \pm 0.6 \mu \mathrm{g} / \mathrm{mL})$ and EAA $(184.1 \pm 1.8 \mu \mathrm{g} / \mathrm{mL})$ for 24 hours. Figure $4(\mathrm{a})$ showed a representative scratch at time 0 of wound initiation. After 24 hours the cells present in the control well (Figure 4(b)) were able to divide and repopulate the space created by the scratch. However, treatment of the cells with both of the AA extracts leads to a decrease in the rate at which the cells were able to divide and thereby migrate into the clear area created by the scratch. Inhibition of wound reepithelialization by AAA extract was more evident through pictorial image as compared to EAA (Figure 4(c)) thereby indicating greater inhibitory effects on cell proliferation leading to much lower migration of cells (Figure 4(d)).

3.7. Clonogenic Cell Survival Assay. A significant decrease in number of colonies present in the treated wells, after an incubation period of 2 weeks, was observed compared to the untreated control well (Figure 5). AAA treated cells at a concentration of $165.7 \pm 0.6 \mu \mathrm{g} / \mathrm{mL}$ showed $42.1 \pm 1.3$ percent decrease in colony forming ability, while EAA treatment at its IC $_{50}(184.1 \pm 1.8 \mu \mathrm{g} / \mathrm{mL})$ showed $56.2 \pm 0.9$ percent reduction in comparison with untreated control which was taken as 100 percent colony forming ability.

3.8. Antiproliferative Assay. To evaluate the effect of AA extracts on proliferation, a direct cell count was performed. We observed that both of the extracts lead to cell killing when they were present in the medium. However, on renewal with fresh medium, both EAA and AAA treated cells responded in different modes. The cytostatic effects were seen in EAA treated cells as displayed in Figure 6(a). The effects were more pronounced at the highest concentration and were also time dependent with $38.5 \pm 0.3$ and $22.6 \pm 0.3$ percent proliferation after 48 hours and after 48 hours of medium replacement, respectively, whereas $24.9 \pm 0.3$ and $27.7 \pm 0.3$ percent reduced proliferation were seen after 72 hours and after 24 hours of medium replacement treatment, at $200 \mu \mathrm{g} / \mathrm{mL}$. Figure 6(b) revealed the cytocidal nature of AAA towards COLO-205 cells, conferring an irreversible action on the cell cycle, with $30.3 \pm 1.8$ and $26.6 \pm 1.4$ percent proliferation after 48 hours and after 48 hours of medium replacement, respectively, whereas $18.7 \pm 1.4$ and $14.3 \pm 1.7$ percent proliferation were seen after 72 hours and after 24 hours of medium replacement treatment at a concentration of $200 \mu \mathrm{g} / \mathrm{mL}$.

3.9. Induction of Apoptosis. The morphological changes in cell nuclei were determined by fluorescence microscope by staining cells with Hoechst 33258 dye. The morphological 


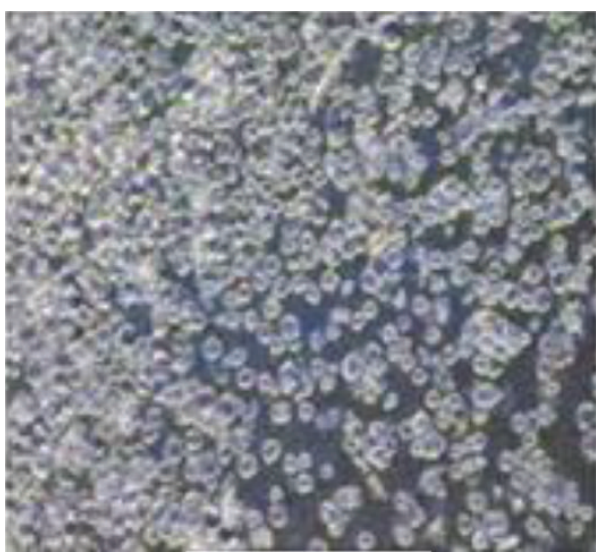

(a)

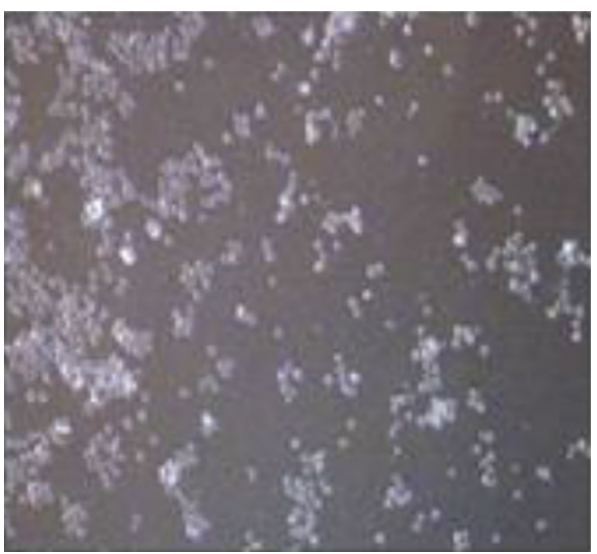

(b)

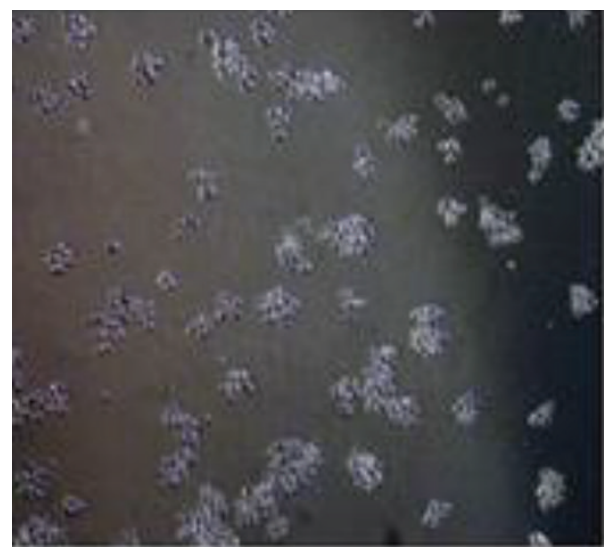

(c)

Figure 3: AA extracts lead to growth inhibition in COLO-205 cells. To study the effect of AAA and EAA on cell growth; COLO-205 cells were treated with $\mathrm{IC}_{50}$ value of the extracts and kept for a period of 72 hours. (a) Control, (b) EAA, and (c) AAA after 72 hours (magnification at $100 x)$.

observation in the cell nuclei of COLO-205 cells after treatment with or without AA root extracts for 72 hours is shown in Figure 7. The untreated cells appeared to be intact and round in shape and the nuclei were stained with a less bright blue fluorescence (Figure 7(a)), whereby cells treated with AA extracts showed evidence of cell shrinkage and chromatin condensation with bright blue fluorescence. However, AAA treatment at its $\mathrm{IC}_{50}$ value (Figure $7(\mathrm{c})$ ) exhibited greater evidence of apoptosis with more pronounced chromatin condensation and segregated bodies as compared to EAA (Figure 7(b)).

Apoptotic cells were also identified by $\mathrm{AO} / \mathrm{EB}$ and annexin V/PI staining. Untreated control cells displayed normal green nucleus (Figure S2 A) while for the same field (Figure S2 B) there was no evidence of red fluorescence as ethidium bromide (EB) is only taken up by cells when cytoplasmic membrane integrity is lost, pointing to the fact that the cells were live. Similar results were also seen in the untreated control cells stained with annexin V/PI (Figure S3 A-B). The cells treated at the $\mathrm{IC}_{50}$ of AAA $(165.7 \pm$ $0.6 \mu \mathrm{g} / \mathrm{mL}$ ) for 72 hours showed marked changes in morphology such as irregular shape, membrane blebbing, and condensed and fragmented chromatin to produce apoptotic bodies with enhanced levels of fluorescent nuclei as observed in Figure S2 E-F and externalisation of phosphatidylserine leading to binding of annexin $\mathrm{V}$ conjugated to FITC with signs of both early (Figure S3 E) and late stage apoptosis (Figure S3 F). All these effects were more pronounced in the AAA treated cells as compared to those treated with EAA (Figure S2-3 C-D).

The ladder like DNA fragmentation is qualitative indicator of apoptosis. No evidence of fragmentation was seen in the control lane marked C (Figure 8). A ladder like pattern of damaged DNA was observed after 72 hours of treatment with $\mathrm{IC}_{50}$ of AAA and EAA. To quantify the degree of DNA fragmentation after 72 hours of treatment the DPA method revealed an increased percentage of fragmentation in AAA treated cells of $35 \pm 2.3 \%$, while EAA treatment leads to $18 \pm 2.1 \%$ in contrast to untreated cells having only $8 \pm 1.2 \%$ fragmented DNA.

3.10. Gut Bacterial Hydrolysis. The growth inhibitory effect of AAA over EAA was clearly evident from the above results. Therefore, AAA was further subjected to gut bacterial 


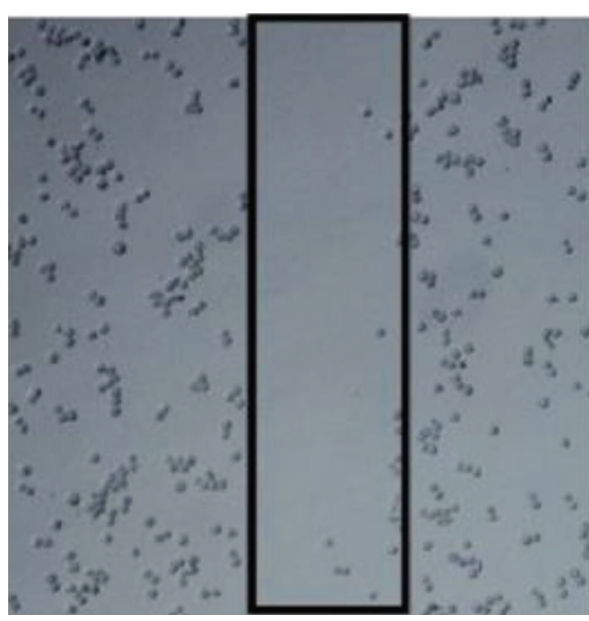

(a)

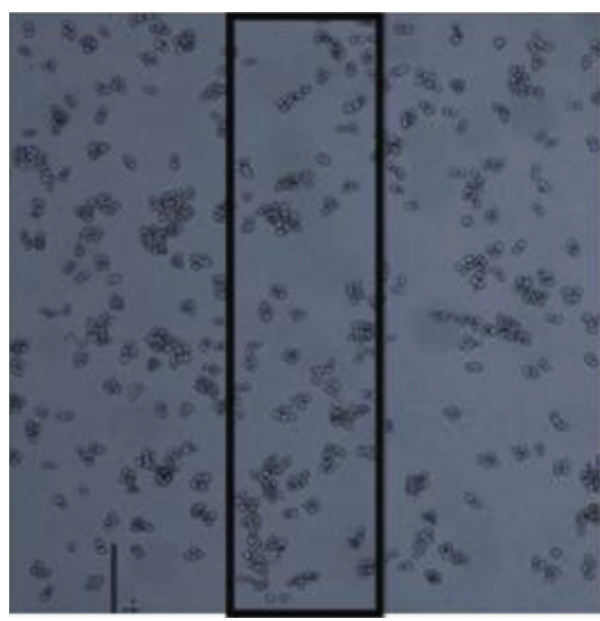

(c)

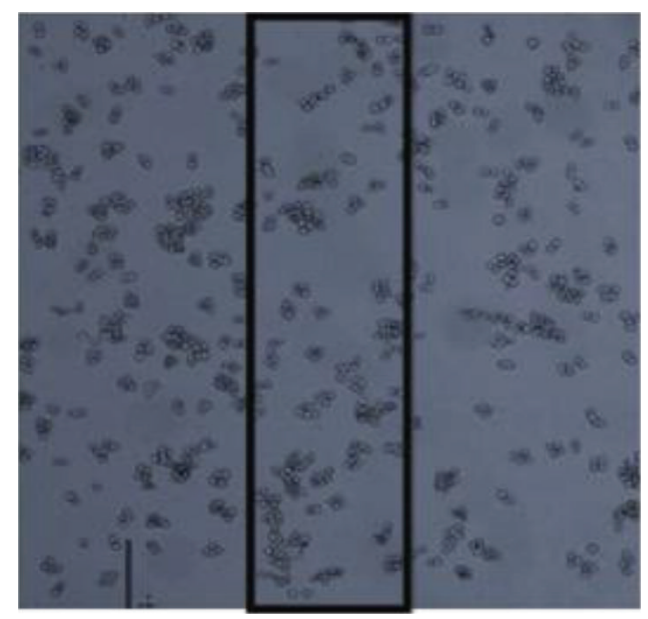

(b)

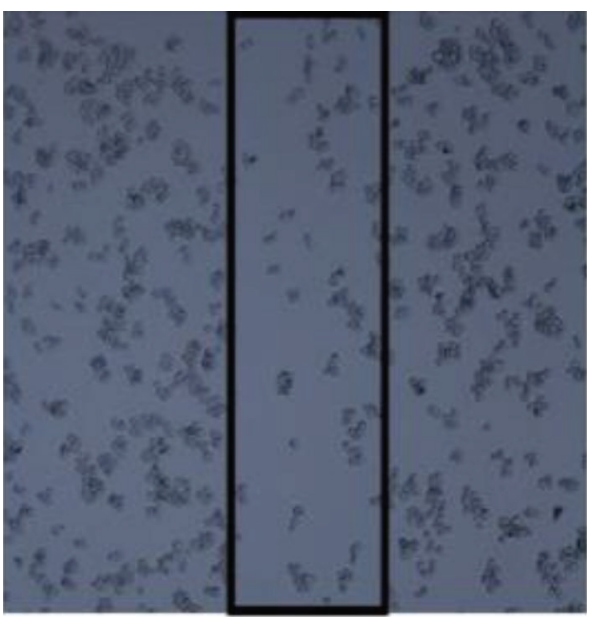

(d)

FIGURE 4: Inhibitory effects of AA extracts on the migration of COLO-205 cells. (a) Initial view of scratch at time 0 , prior to any treatment, (b) control, after 24 hours, (c) EAA treated cells at 24 hours, and (d) AAA treated cells at 24 hours.

hydrolysis, to check whether it is inherently cytotoxic or acts as a prodrug, which needs some modification to its original form to become fully active within the human body. Treatment of the various concentrations of the AAA extract with metabolic enzyme prior to cytotoxicity testing showed an increased percent cytotoxicity which was significant. The most significant effect was seen at $250 \mu \mathrm{g} / \mathrm{mL}$, wherein the cytotoxicity increased from $67.1 \pm 1.2$ to $79.2 \pm 1.6$ percent $(P<0.001)$. The inference drawn from this result indicates that AAA is behaving as a prodrug, which needs to be further acted upon by enzymes present within the body to enhance its cytotoxicity within the system (Figure S4).

3.11. Gene Expression Studies. RT-PCR analysis revealed a significant upregulation in the expression of proapoptotic genes such as caspase-3, caspase-9, and Bax in the AAA treated cells as compared to control. At the same time, expression of the antiapoptotic $\mathrm{Bcl}-2$ gene was downregulated upon treatment of COLO-205 cells with AAA at its $\mathrm{IC}_{50}$ value of $165.7 \pm 0.6 \mu \mathrm{g} / \mathrm{mL}$. The fold change in gene expression between untreated and AAA treated cells after 72 hours was calculated and an increment in the expression of caspase- 9 from 1.0 to $1.24(P<0.05)$ with a concomitant increase in the level of caspase- 3 which is the executioner caspase, from 1.0 to $1.9(P<0.01)$. An increase in the ratio of $\mathrm{Bax} / \mathrm{Bcl}-2$ in the AAA treated cells to 1.33 from 0.39 in the untreated controls $(P<0.01)$ was seen which signifies propensity towards apoptosis (Figures 9(a) and 9(b)). These results point towards the involvement of the intrinsic pathways of apoptosis induced by the AAA in COLO-205 cells.

3.12. Cell Cycle Analysis. Cell cycle phase distribution was analyzed by flow cytometry with PI staining and the percentage of cells in $\mathrm{G}_{0} / \mathrm{G} 1, \mathrm{~S}$, and $\mathrm{G} 2 / \mathrm{M}$ phases was calculated using CFlow Plus software. Histograms of the flow cytometric data are shown in Figure 10. In untreated cells, $60.9 \pm 1.9$, $18.2 \pm 1.7$, and $18.6 \pm 2.1$ percent of the cells were distributed among $\mathrm{G}_{0} / \mathrm{G} 1, \mathrm{~S}$, and G2/M phase, respectively. Exposure of cells to AAA $(165.7 \pm 0.6 \mu \mathrm{g} / \mathrm{mL})$ for 72 hours resulted in cell accumulation at $S$ phase with $59.6 \pm 1.4,30.2 \pm 2.1$, and 


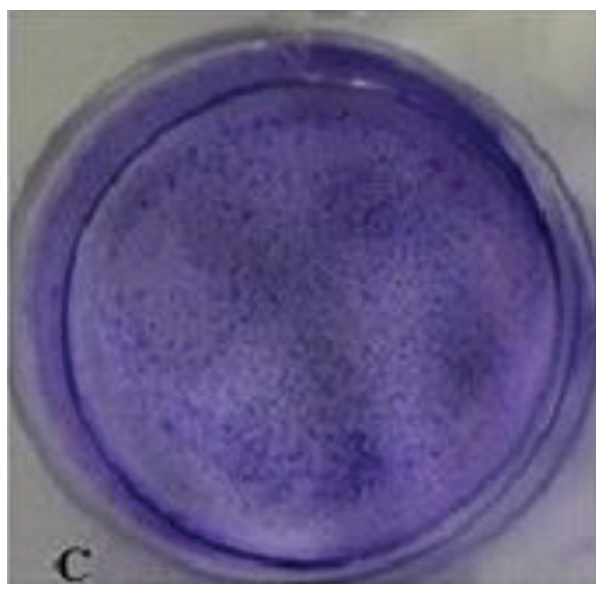

(a)

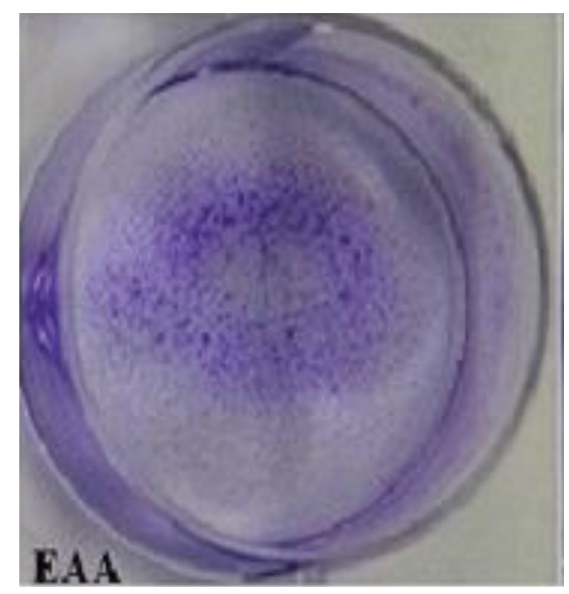

(b)

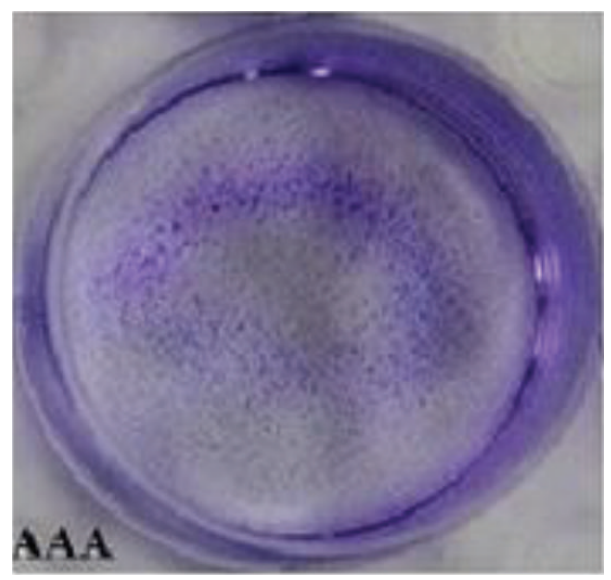

(c)

FIgURE 5: Colony formation inhibition of COLO-205 cells on treatment with AA extracts for 14 days. Cells were fixed with $4 \%$ paraformaldehyde and stained with crystal violet. "C" control untreated well "EAA" and "AAA" represents the treated wells.

$3.5 \pm 1.6$ percent distribution in $\mathrm{G}_{0} / \mathrm{G} 1, \mathrm{~S}$, and $\mathrm{G} 2 / \mathrm{M}$ phase, respectively. This arrest was accompanied by increase in levels of p16, p21, and p27 as compared to untreated controls from 1 to $1.4(P<0.05), 1$ to $2.1(P<0.01)$, and 1 to $2.6(P<0.01)$ (Figures 11(a) and 11(b)), which are inhibitors of cell cycle and could provide an explanation of cell cycle inhibition.

3.13. GC-MS Analysis. GC-MS chromatogram of the AAA extract showed ten peaks indicating the presence of ten chemical constituents. On comparison of the mass spectra of the constituents with the NIST library the ten constituents were characterized and identified (Figure S5). The total MS running time was 32 minutes. The active principles with their retention time (RT), molecular formula, and peak area (\%) in AAA extracts are presented in Supplementary Table S2.

\section{Discussion}

Plants have always represented a rich source of compounds that possess unique medicinal properties. The benefit of herbs already exists in the ancient literature of Ayurveda and Unani medicine [6]. Various secondary metabolites are known to act as anticancer agents $[30,31]$. Therefore, AAA and EAA containing these compounds may serve as a potential source of bioactive compounds in the treatment of colon cancer. The TPC values were found to be more in EAA than AAA. Also, the results from antioxidant assay showed EAA to possess greater capability to scavenge the free radicals in comparison to AAA, suggesting greater proportion of phenolics in EAA which are known to act as free radical scavengers. Others have also documented the positive correlation between free radical scavenging activity and TPC value $[32,33]$ and similar observation was seen in our study. The cell viability assay was performed to determine the effect of AA root extracts on viability of COLO-205 cells. The results showed a dose and time dependent response in growth inhibition which was more pronounced in AAA and was in agreement with the MTT assay. Although antioxidants have been linked to cytotoxicity, we observed that AAA was more cytotoxic than EAA, even though EAA possessed higher TPC and antioxidant activity. These findings suggested the presence of active compounds other than phenolics present in AAA that may be responsible for its cytotoxic effect. Indeed, 


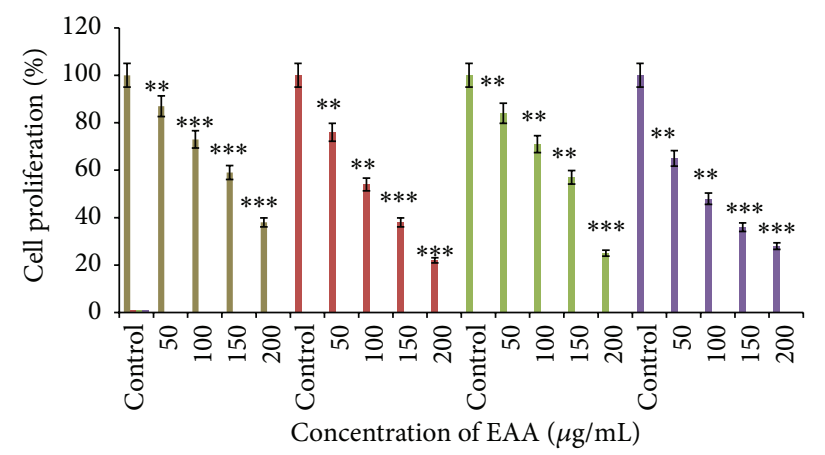

48 hours of treatment

- After 48 hours of treatment

72 hours of treatment

- After 24 hours of treatment

(a)

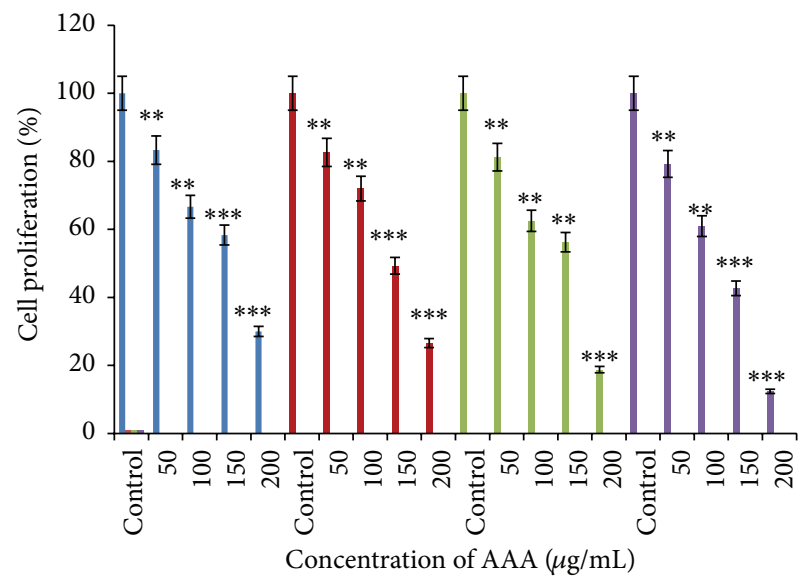

48 hours of treatment

- After 48 hours of treatment

- 72 hours of treatment

- After 24 hours of treatment

(b)

Figure 6: Antiproliferative effect of AA extracts on COLO-205 cells: (a) EAA and (b) AAA. Data presented as percent proliferation of treated cells $(n=3)$ compared to untreated control cells. ${ }^{*} P<0.05,{ }^{* *} P<0.01$, and ${ }^{* * *} P<0.001$.

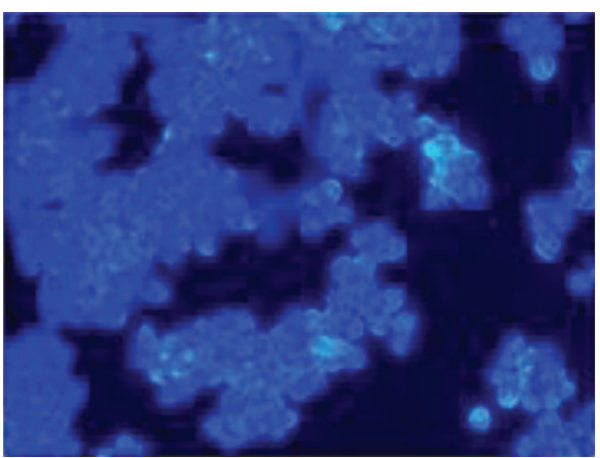

(a)

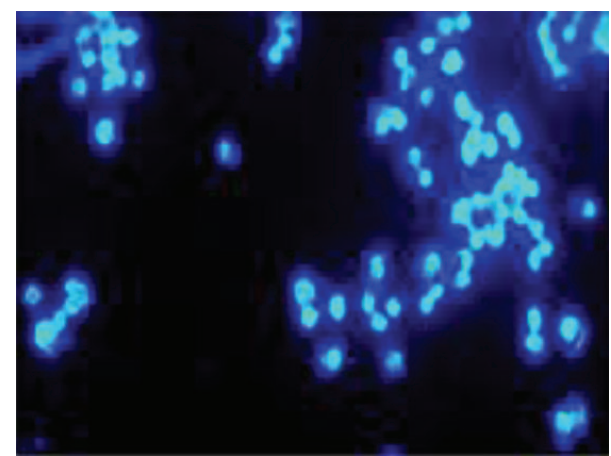

(b)

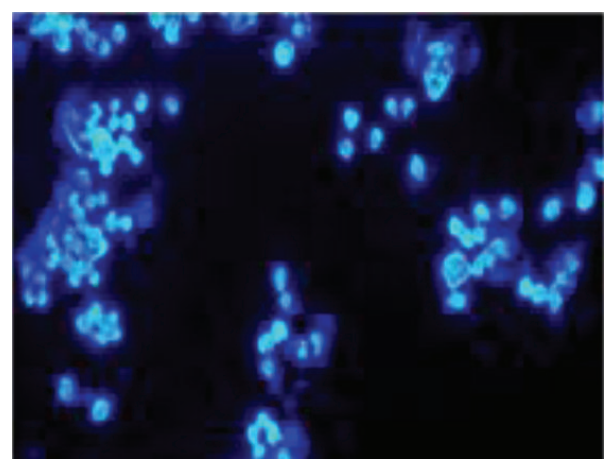

(c)

FIGURE 7: Evaluation of apoptotic changes in COLO-205 cells by Hoechst 33258 staining. (a) Control, (b) EAA, and (c) AAA (magnification 100x). 


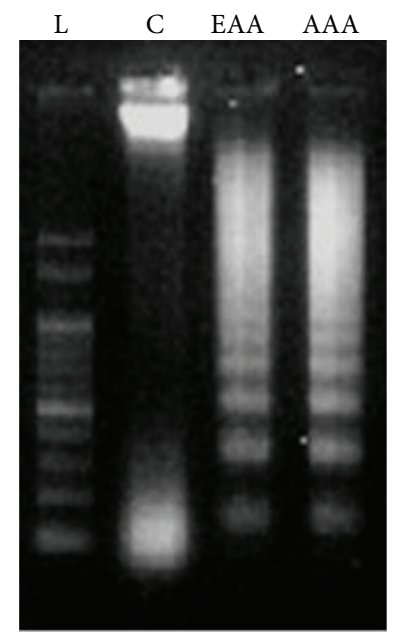

FIgURE 8: AA extracts lead to induction of DNA fragmentation in the COLO-205 cells. Lane 1: 100 bp ladder, lane 2: untreated control cells, lane 3: EAA treated cells, and lane 4: AAA treated cells.

previous phytochemical investigations have suggested that roots of AA are rich in saponins, which could explain greater cytotoxic effect in AAA treated cells $[33,34]$. In addition in our previous studies to ascertain selectivity of CAM therapies towards cancer cells, we have demonstrated that AA root extracts display no significant cytotoxicity on normal epithelial cells [35]. These results, taken together, point the specificity towards COLO-205 cells and the effectiveness of CAM therapies over conventional ones.

Wound healing is a cellular process which allows cells to restore their original architecture and function in their wound site [17]. This property of malignant cells was reversed on application of EAA and AAA, wherein treatment with AAA was able to halt the process of migration to a greater extent in comparison to EAA, indicating that AAA has the potential to prevent metastasis. Clonogenic cell survival assay was used in our study to determine antiproliferative effects of AA extracts by checking its ability to inhibit cancer cells from dividing and forming colonies. AAA treated cells were shown to exhibit greater effect on colony formation over EAA treated cells indicating that AAA possesses certain botanical compounds which can impinge upon the cell cycle leading to arrest of cell growth. Reduction in growth of cancer cells after treatment with various plant extracts was also observed by other researchers, indicating alterations in growth kinetics of cancer cells [36].

The assessment of proliferative behaviour of cells is a noteworthy step as most of the anticancer drugs are less cytocidal to quiescent cells than to actively proliferating cells [37]. Antiproliferative effect of any agent/extract can have 2 possible outcomes on cell growth. When the extract stops or delays the cell from dividing, it said to be cytostatic and this may be reversible thereby allowing a cell to undergo multiplication in fresh medium even after the specific treatment. The second category highlights the cytocidal/irreversible nature of an extract, which involves killing of cells with no further increase in cell number even after removal of medium containing the extract [38]. The results of the proliferation assay have thrown some interesting light on the mechanism of action of AA. The AAA treated cells significantly showed greater cytocidal effect thereby hindering the multiplication of the cells in an irreversible manner in comparison with the cytostatic EAA treated cells at their highest concentration, after 72 hours of treatment. Our results were in agreement with a number of plant based botanicals which form a part of traditional medicines which acting in a similar manner either make the cells undergo apoptosis or make the cells exit the cell cycle and into the $\mathrm{G}_{0}$ stage. Curcumin, a diarylheptanoid derivative of turmeric, has also been attributed in suppression of cell proliferation by altering the cell cycle in various in vitro colon cancer models [39].

The antiproliferative and cytotoxic effects of AA root extracts are likely to be linked via activation of apoptosis. The cell death was identified by a phase contrast microscopy, which revealed abundance of morphological alterations including loss of cell viability, irregular shape, and cellular detachment in AAA treated cells as compared to EAA treated cells. The apoptotic cell death in treated cells was observed by different assays indicating characteristic leading to cell death. Studies on plant extract mediated apoptosis point towards the role of the intrinsic pathway. Euphorbia formosana root extract induced the intrinsic pathway in THP-1 human leukemic cells [40]. Increased expression of the proapoptotic protein (Bax), along with reduced level of the antiapoptotic protein $(\mathrm{Bcl}-$ 2), was observed in breast cancer MCF-7 cells after treatment with Lethariella zahlbruckneri extract [41]. In our investigation we too observed increased levels of caspase-9, caspase- 3 , and Bax, along with decreased expression of Bcl-2 in AAA treated cells, thereby confirming the induction of apoptosis in COLO-205 cells via mitochondrial pathway.

An altered regulatory mechanism prevalent in the cell cycle plays pivotal role in the growth of various types of cancer cell and is an important target in cancer therapy. The aqueous extracts of AA were able to induce their antiproliferative activity as seen in the form of antimigration and inhibition of colony formation properties in part, by deregulating the cell cycle as revealed by an increase in the percentage of cells in the $S$ phase. For a cell to be able to divide into two daughter cells the synthesis and duplication of the DNA are an absolute requirement and any abnormality in this would lead to a halt in the cell cycle progression. The phenomenon of DNA damage is a continuous setback that cells must deal with and impacts their viability and proliferation. Failure to undergo the repair to damaged DNA generally leads to alterations in genome resulting in multistep mutations leading to carcinogenesis [42]. Several checkpoints have been employed by the cell to identify and repair the DNA damage by halting/stalling their progress through the various phases of the cell cycle such as $\mathrm{G}_{0} / \mathrm{G} 1, \mathrm{~S}$, and $\mathrm{G} 2 / \mathrm{M}$ checkpoints. We observed arrest at $S$ phase of cell cycle upon AAA treatment leading to a halt in cell cycle progression. A number of CAM sources have exhibited significant inhibitory effects on cancer cells via disruption of cell cycle progression. Amongst various traditional Chinese medicines (TCM), Ganoderma is the one of commonly used herbal 


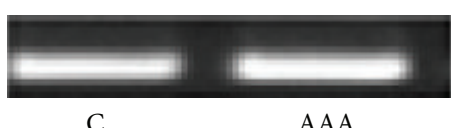

(A)

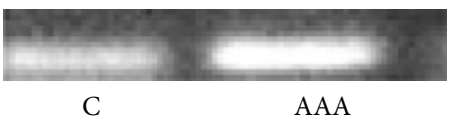

(B)

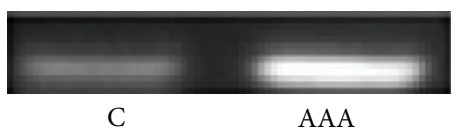

(C)

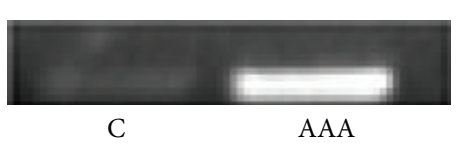

(D)

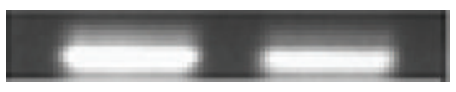

C

(E)

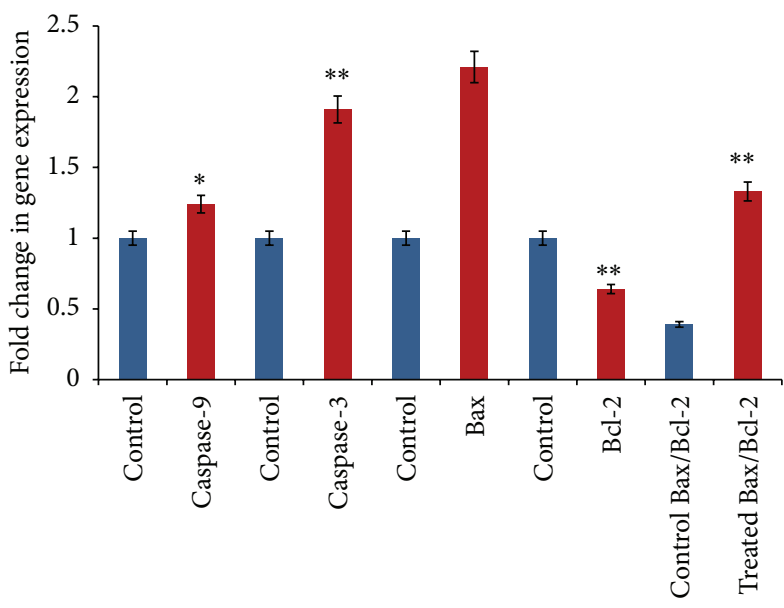

Untreated cells

AAA treated cells

(a)

(b)

FIGURE 9: (a) AAA induced activation of intrinsic apoptotic pathway in COLO-205 cells. Agarose gel electrophoresis of PCR products of (A) $\beta$-actin, (B) caspase-9, (C) caspase-3, (D) Bax, and (E) Bcl-2 genes. (b) The fold change in expression of apoptosis-associated gene after AAA treatment. The densitometric analysis was done of the PCR products of caspase- 9 , caspase-3, Bax, and Bcl-2 genes to measure the fold change in each gene and was normalised to the house-keeping gene $\beta$-actin. Data presented as fold change in gene expression between AAA treated cells and untreated control cells. ${ }^{*} P<0.05 ;{ }^{* *} P<0.01$.

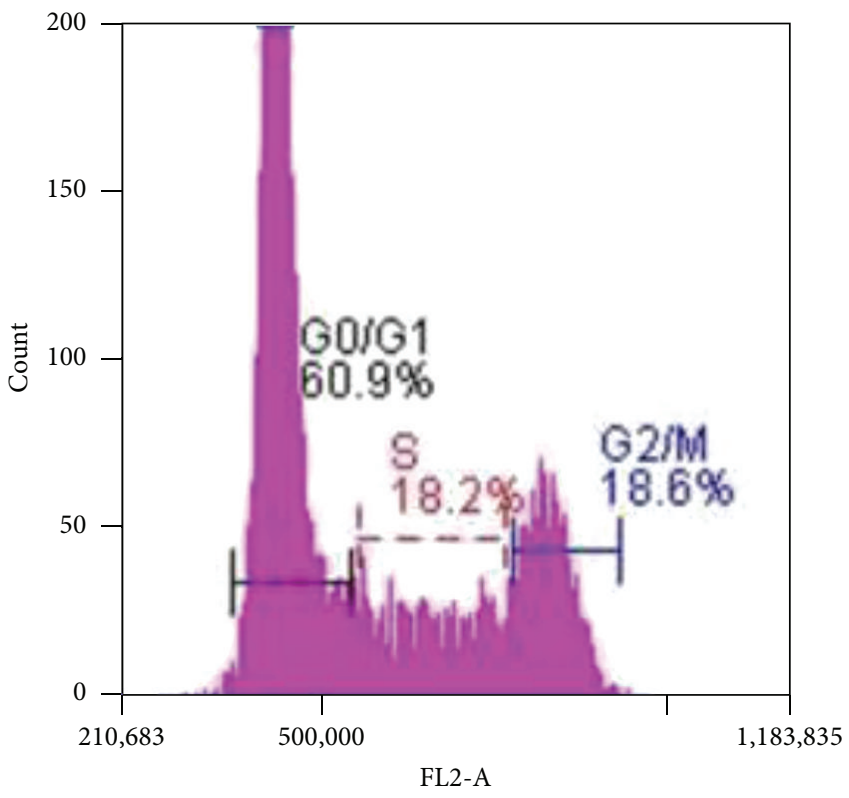

(a)

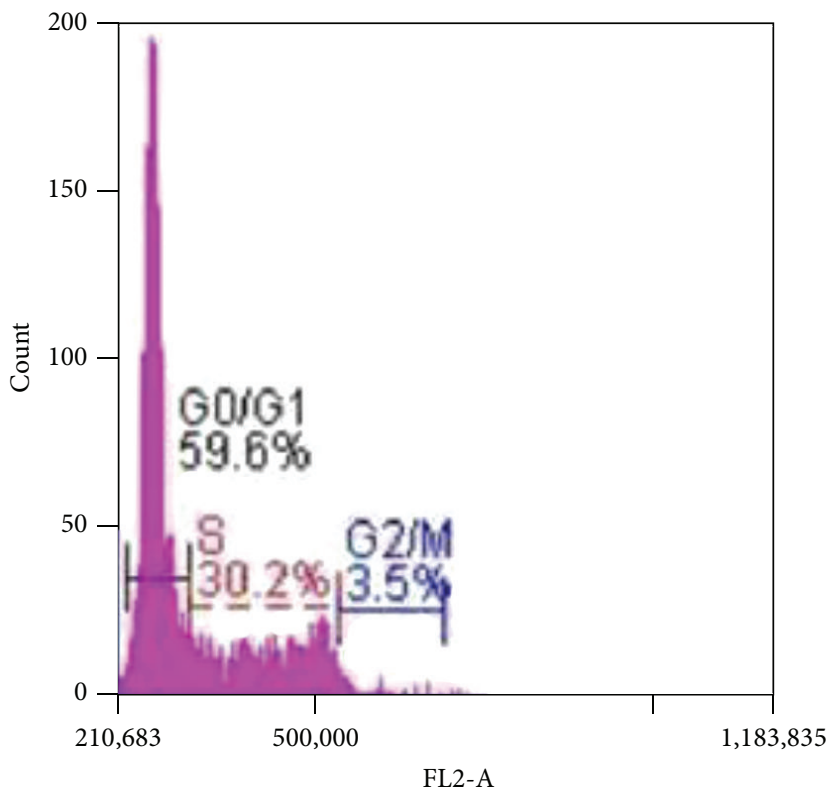

(b)

Figure 10: AAA leads to S phase arrest in COLO-205 cells. (a) Histogram of cell cycle distribution of control untreated cells. (b) Histogram of cell cycle distribution of AAA treated cells as assessed by flow cytometry. 


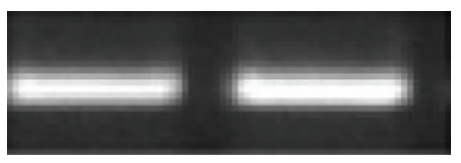

(A)

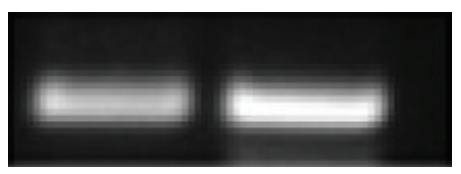

(B)

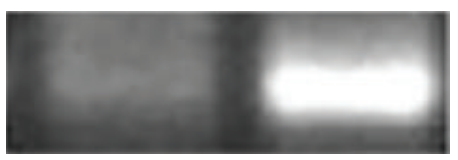

(C)

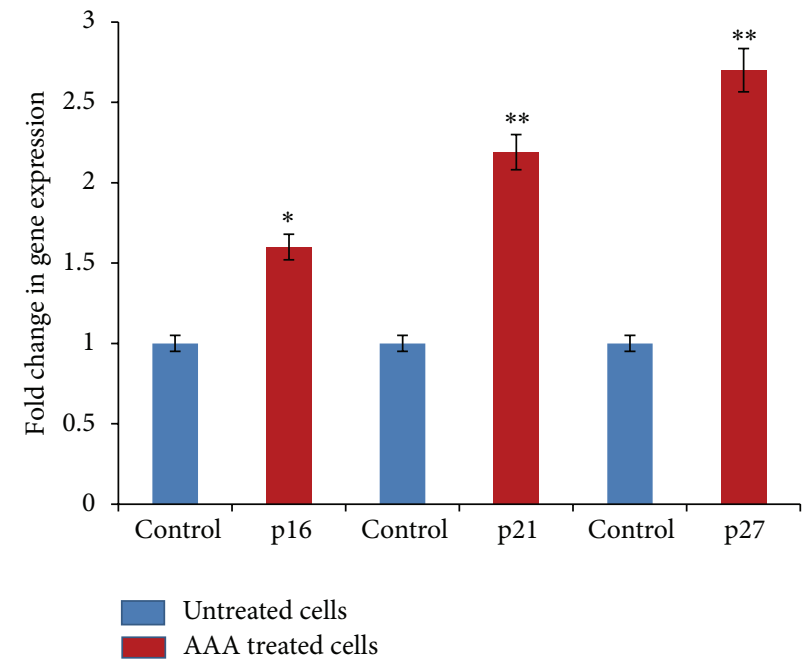

(D)

AAA treated cells

(a)

(b)

FIGURE 11: (a) CKI upregulation by AAA induces cell cycle arrest in COLO-205 cells. Agarose gel electrophoresis of PCR products of (A) $\beta$-actin, (B) p16, (C) p21, and (D) p27 genes. (b) The fold change in expression of CKI's gene after AAA treatment. The densitometric analysis was done of the PCR products p16, p21, and p27 gene to measure the fold change in each gene and was normalised to house-keeping gene $\beta$-actin. Data presented as fold change in gene expression between AAA treated cells and untreated control cells. ${ }^{*} P<0.05 ;{ }^{* *} P<0.01$.

medicine in Asia. Studies have shown that treatment with the chloroform extract of Ganoderma causes cell cycle arrest in cells [43]. Growth inhibitory effect of celery seed extracts on human gastric cancer BGC-823 cells was determined, which was associated with cycle arrest in the $\mathrm{S}$ phase and decreased levels of cyclin A and CDK-2 [44]. The crude water extract of Centella asiatica showed $\mathrm{S}$ and $\mathrm{G} 2 / \mathrm{M}$ arrest in human colon adenocarcinoma-derived Caco-2 cells, accompanied with accumulation of cyclin B1 protein in the cells [45].

In order to get a clearer insight into the underlying mechanism for cell cycle arrest by AAA, the regulatory genes of the cell cycle were evaluated, namely, the cyclin dependent kinase inhibitors, or CKIs, p16, p21, and p27 genes. An upregulation of p16, p21, and p27 level in AAA treated cells indicated stimulatory role of AAA in activation of inhibitors of cell cycle progression thereby causing an arrest in cell cycle process. Several plants have shown the role of CKI in inhibition of cancer cell progression. An increase in p53, p21WAF1/Cip1, and p27Kip1 levels, indicators of cell cycle arrest, was observed in murine B16F10 melanoma cells on treatment with Moringa oleifera Lam., Eremomastax speciosa (Hochst.) Cufod., and Aframomum melegueta K. Schum. extracts. [46]. DATS, a garlic-derived organosulfur compound, showed growth inhibitory effects on pancreatic cancer cells (Capan-2) through elevated levels of cyclin B1 and p21 and reduced levels of cyclin D1 [47].
For investigation of volatile biological compounds present in AAA extract, GC-MS analysis was done and the mass spectra revealed the presence of 10 compounds. The spectrum of the unknown component was compared with the spectrum of the known components stored in the NIST library. Hence, the identified phytocomponents using GC-MS can be further isolated and studies on their biological activity in an in vitro system can be done.

\section{Conclusion}

In conclusion, our findings indicate that the aqueous extract of Achyranthes aspera suppresses the cell proliferation and increases cytotoxicity in a dose and time dependent manner in colon cancer cells. This ability of AAA could be attributed to the induction of apoptosis via the mitochondrial-mediated pathway and arresting the cells in $S$ phase of cell cycle in COLO-205 cells. However, the exact mechanisms and the molecular determinants that are responsible for the initiation of apoptosis need to be addressed. Thus, further studies on AAA as a novel therapeutic agent having anticancer activity, originating from plants, are warranted.

\section{Conflict of Interests}

The authors declare that there is no conflict of interests regarding the publication of this paper. 


\section{Acknowledgments}

The authors are extremely thankful to the Department of Biotechnology and Bioinformatics, Jaypee University of Information Technology, Solan, for funding this research. They also wish to express their gratitude towards Natural Remedies Pvt. Limited, Bangalore, for providing sample for this work.

\section{References}

[1] IARC, "Colorectal cancer incidence and mortality worldwide in 2012," Globocan Cancer Fact Sheet, Globocan, 2013.

[2] S. Fulda and K.-M. Debatin, "Apoptosis pathways in neuroblastoma therapy," Cancer Letters, vol. 197, no. 1-2, pp. 131-135, 2003.

[3] R. S. Y. Wong, "Apoptosis in cancer: from pathogenesis to treatment," Journal of Experimental and Clinical Cancer Research, vol. 30, no. 1, article 87, 2011.

[4] S. Haupt, M. Berger, Z. Goldberg, and Y. Haupt, "Apoptosisffkthe p53 network," Journal of Cell Science, vol. 116, no. 20, pp. 4077-4085, 2003.

[5] M. Rebucci and C. Michiels, "Molecular aspects of cancer cell resistance to chemotherapy," Biochemical Pharmacology, vol. 85, no. 9, pp. 1219-1226, 2013.

[6] M. Srivastav, P. Singh, G. Mishra, K. K. Jha, and R. L. Khosa, "Achyranthes aspera-an important medicinal plant: a review," Journal of Natural Products and Plant Resource, vol. 1, pp. 1-14, 2011.

[7] P. R. Subbarayan, M. Sarkar, S. Impellizzeri et al., "Antiproliferative and anti-cancer properties of Achyranthes aspera: specific inhibitory activity against pancreatic cancer cells," Journal of Ethnopharmacology, vol. 131, no. 1, pp. 78-82, 2010.

[8] S. B. Kota, P. Sivakumar, T. Karthiyayini, M. Rajkumar, and K. L. Kumar, "In-Vitro anti-cancer activity of ethanolic extract of the leaves of Achyranthes bidentata (Blume)," Research Journal of Pharmaceutical, Biological and Chemical Sciences, vol. 3, p. 519, 2012.

[9] J. Nguyen-Pouplin, H. Tran, T. A. Phan et al., "Antimalarial and cytotoxic activities of ethnopharmacologically selected medicinal plants from South Vietnam," Journal of Ethnopharmacology, vol. 109, no. 3, pp. 417-427, 2007.

[10] P. R. Subbarayan, M. Sarkar, S. Nagaraja Rao et al., "Achyranthes aspera (Apamarg) leaf extract inhibits human pancreatic tumor growth in athymic mice by apoptosis," Journal of Ethnopharmacology, vol. 142, no. 2, pp. 523-530, 2012.

[11] A.-A. Baskar, K.-S. Al Numair, M.-A. Alsaif, and S. Ignacimuthu, "In vitro antioxidant and antiproliferative potential of medicinal plants used in traditional indian medicine to treat cancer," Redox Report, vol. 17, no. 4, pp. 145-156, 2012.

[12] S. Edwin, E. E. Jarald, L. Deb et al., "Wound healing and antioxidant activity of Achyranthes aspera," Pharmaceutical Biology, vol. 46, no. 12, pp. 824-828, 2008.

[13] V. N. Deshmukh, J. Y. Nehete, V. V. Shewale, N. A. Rarhav, and V. T. Gawande, "Gastric antiulcer activity of Achyranthes aspera roots in pylorous liagted rats," Global Journal of Pharmacology, vol. 5, pp. 143-146, 2011.

[14] S. Tandon, A. Arora, S. Singh, J. Monga, and S. Arora, "Antioxidant profiling of Triticum aestivum (wheatgrass) and its antiproliferative activity in MCF-7 breast cancer cell line," Journal of Pharmacy Research, vol. 4, pp. 4601-4604, 2011.
[15] M. H. Roudkenar, R. Halabian, A. M. Roushandeh et al., "Lipocalin 2 regulation by thermal stresses: protective role of Lcn2/NGAL against cold and heat stresses," Experimental Cell Research, vol. 315, no. 18, pp. 3140-3151, 2009.

[16] J. Monga, S. Pandit, C. S. Chauhan, and M. Sharma, "Cytotoxicity and apoptosis induction in human breast adenocarcinoma MCF-7 cells by (+)-cyanidan-3-ol," Experimental and Toxicologic Pathology, vol. 65, no. 7-8, pp. 1091-1100, 2013.

[17] J. Manoj, T. Kumar, S. Varghese, and K. Murugan, "The effect of methanol and water extract of leucobryum bowringii Mitt on growth, migration and invasion of MCF-7 human breast cancer cell lines in vitro," Indian Journal of Experimental Biology, vol. 50, no. 9, pp. 602-611, 2012.

[18] N. A. P. Franken, H. M. Rodermond, J. Stap, J. Haveman, and C. van Bree, "Clonogenic assay of cells in vitro," Nature Protocols, vol. 1, no. 5, pp. 2315-2319, 2006.

[19] S. Allen, J. Sotos, M. J. Sylte, and C. J. Czuprynski, "Use of hoechst 33342 staining to detect apoptotic changes in bovine mononuclear phagocytes infected with Mycobacterium avium subsp. paratuberculosis," Clinical and Diagnostic Laboratory Immunology, vol. 8, no. 2, pp. 460-464, 2001.

[20] D. Ribble, N. B. Goldstein, D. A. Norris, and Y. G. Shellman, "A simple technique for quantifying apoptosis in 96-well plates," BMC Biotechnology, vol. 5, article 12, pp. 1472-6750, 2005.

[21] M. V. S. Castello-Branco, J. F. Tavares, M. S. Silva et al., "Xylodiol from Xylopia langsdorfiana induces apoptosis in HL60 cells," Brazilian Journal of Pharmacognosy, vol. 21, no. 6, pp. 1035-1042, 2011.

[22] O. A. Abu Zinadah, W. K. Khalil, H. M. El Ashmaoui, F. Abdu, and M. E. Abou Alsoud, "Evaluation of the anti-genotoxicity and growth performance impacts of green algae on Mugil cephalus," Life Science Journal, vol. 10, no. 3, pp. 1543-1554, 2013.

[23] P. Houghton, R. Fang, I. Techatanawat, G. Steventon, P. J. Hylands, and C. C. Lee, "The sulphorhodamine (SRB) assay and other approaches to testing plant extracts and derived compounds for activities related to reputed anticancer activity," Methods, vol. 42, no. 4, pp. 377-387, 2007.

[24] E. Azizi, M. H. Abdolmohammadi, S. Fouladdel, A. Shafiee, G. Amin, and S. M. Ghaffari, "Evaluation of p53 and BCL-2 genes and proteins expression in human breast cancer T47D cells treated with extracts of Astrodaucus persicus (Boiss.) drude in comparison to tamoxifen," Daru, vol. 17, no. 3, pp. 181-186, 2009.

[25] S. C. Choi, D. K. Kwang, J. T. Kim et al., "Expression of human NDRG2 by myeloid dendritic cells inhibits down-regulation of activated leukocyte cell adhesion molecule (ALCAM) and contributes to maintenance of $\mathrm{T}$ cell stimulatory activity," Journal of Leukocyte Biology, vol. 83, no. 1, pp. 89-99, 2008.

[26] H. Y. Tsuan, C. Lu, J. S. Yang et al., "Berberine induced apoptosis via promoting the expression of caspase- $8,-9$ and -3 , apoptosisinducing factor and endonuclease G in SCC-4 human tongue squamous carcinoma cancer cells," Anticancer Research, vol. 29, no. 10, pp. 4063-4070, 2009.

[27] L.-H. Shang, C.-M. Li, Z.-Y. Yang, D.-H. Che, J.-Y. Cao, and Y. Yu, "Luffa echinata Roxb. induces human colon cancer cell (HT29) death by triggering the mitochondrial apoptosis pathway," Molecules, vol. 17, no. 5, pp. 5780-5794, 2012.

[28] Q. Ling, X. Xu, X. Wei et al., "Oxymatrine induces human pancreatic cancer PANC-1 cells apoptosis via regulating expression of Bcl-2 and IAP families, and releasing of cytochrome c," Journal of Experimental and Clinical Cancer Research, vol. 30, no. 1, article 66, 2011. 
[29] P. Pozarowski and Z. Darzynkiewicz, Checkpoint Controls and Cancer, Vol. 2: Activation and Regulation Protocols, vol. 281 of Methods in Molecular Biology, Humana Press, 2004.

[30] G. M. Cragg and D. J. Newman, "Plants as a source of anticancer agents," Journal of Ethnopharmacology, vol. 100, no. 1-2, pp. 72-79, 2005.

[31] M. J. Nirmala, A. Samundeeswari, and D. Sankar, "Natural plant resources in anti-cancer therapyffka review," Research in Plant Biology, vol. 1, no. 3, pp. 1-14, 2011.

[32] R. B. Desi Reddy, P. Narisi Reddy, N. Prathibha, T. Madhu Mounica, A. Phanikumar, and M. Ravindra, "Pharmacognostic, preliminary phyto chemical and pharmacological studies on the roots of achyranthes aspera," International Journal of Pharmacognosy and Phytochemical Research, vol. 4, no. 3, pp. 139-141, 2012.

[33] S. K. Sharma, N. Vasudeva, and M. Ali, "A new aliphatic acid from Achyranthes aspera Linn. roots," Indian Journal of Chemistry B: Organic and Medicinal Chemistry, vol. 48, no. 8, pp. 1164-1169, 2009.

[34] H. H. Yoo, S. W. Kwon, and J. H. Park, "The cytotoxic saponin from heat-processed Achyranthes fauriei roots," Biological and Pharmaceutical Bulletin, vol. 29, no. 5, pp. 1053-1055, 2006.

[35] S. Arora, C. Tandon, and S. Tandon, "Evaluation of the cytotoxic effects of CAM therapies: an in vitro study in normal kidney cell lines," The Scientific World Journal, vol. 2014, Article ID 452892, 11 pages, 2014.

[36] S. Samarghandian, M. H. Boskabady, and S. Davoodi, "Use of in vitro assays to assess the potential antiproliferative and cytotoxic effects of saffron (Crocus sativus L.) in human lung cancer cell line," Pharmacognosy Magazine, vol. 6, no. 24, pp. 309-314, 2010.

[37] A. S. Moghe, S. G. Gangal, and P. R. Shilkar, "In vitro cytotoxicity of Bryonia laciniosa (Linn.) Naud. on human cancer cell lines," Indian Journal of Natural Products and Resources, vol. 2, no. 3, pp. 322-329, 2011.

[38] K. Ando, M. Urano, and S. Koike, "Cytocidal and cytostatic ability of Corynebacterium liquefaciens in mouse squamous cell carcinoma in vivo," Cancer Research, vol. 38, no. 6, pp. 1769$1773,1978$.

[39] G. Sa and T. Das, "Anti cancer effects of curcumin: cycle of life and death," Cell Division, vol. 3, article 14, 2008.

[40] Y.-J. Hsieh, C.-J. Chang, C.-F. Wan et al., "Euphorbia formosana root extract induces apoptosis by caspase-dependent cell death via fas and mitochondrial pathway in THP-1 human leukemic cells," Molecules, vol. 18, no. 2, pp. 1949-1962, 2013.

[41] J. H. Lee, Y. K. Lee, J. Y. Kim, J. S. Hur, M. K. Lee, and K. Seo, "Lethariella zahlbruckneri acetone extract-induced apoptosis of MCF-7 human breast cancer cells involves caspase cascade and mitochondria-mediated death signaling," Journal of Nutrition and Food Science, 2012.

[42] D. Hanahan and R. A. Weinberg, "Hallmarks of cancer: the next generation," Cell, vol. 144, no. 5, pp. 646-674, 2011.

[43] G. Wang, J. Zhang, T. Mizuno et al., "Antitumor active polysaccharides from the Chinese mushroom Songshan lingzhi, the fruiting body of Ganoderma tsugae," Bioscience, Biotechnology, and Biochemistry, vol. 57, no. 6, pp. 894-900, 1993.

[44] L.-L. Gao, L. Feng, S.-T. Yao et al., "Molecular mechanisms of celery seed extract induced apoptosis via $S$ phase cell cycle arrest in the BGC-823 human stomach cancer cell line," Asian Pacific Journal of Cancer Prevention, vol. 12, no. 10, pp. 2601-2606, 2011.

[45] P. Bunpo, K. Kataoka, H. Arimochi et al., "Centella asiatica extract induces cell cycle arrest in Caco-2 human colon cancer cells," Chiang Mai Medical Bulletin, vol. 44, pp. 21-28, 2005.
[46] A. Gismondi, L. Canuti, S. Impei et al., "Antioxidant extracts of African medicinal plants induce cell cycle arrest and differentiation in B16F10 melanoma cells," International Journal of Oncology, vol. 43, no. 3, pp. 956-964, 2013.

[47] H.-B. Ma, S. Huang, X.-R. Yin, Y. Zhang, and Z.-L. Di, "Apoptotic pathway induced by diallyl trisulfide in pancreatic cancer cells," World Journal of Gastroenterology, vol. 20, no. 1, pp. 193-203, 2014. 


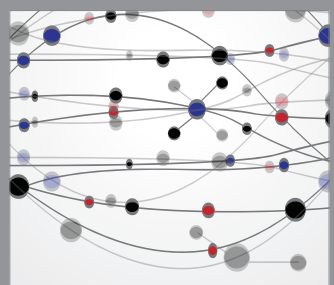

The Scientific World Journal
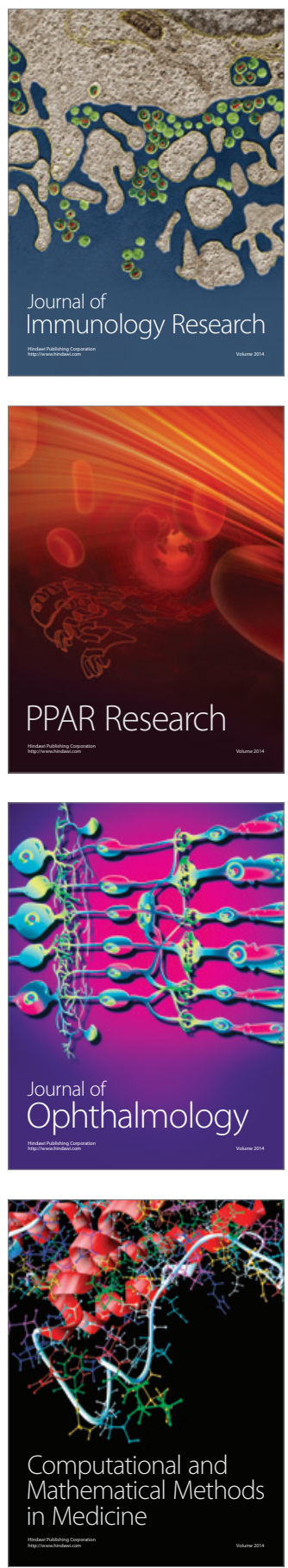

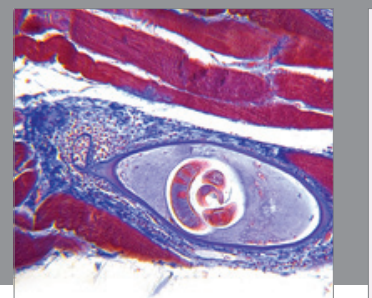

Gastroenterology

Research and Practice
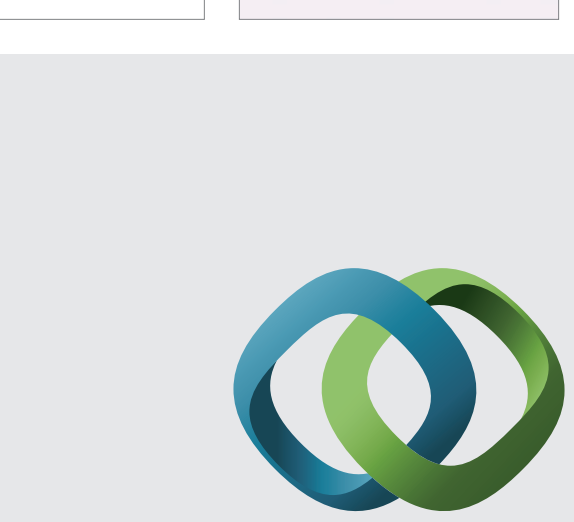

\section{Hindawi}

Submit your manuscripts at

http://www.hindawi.com
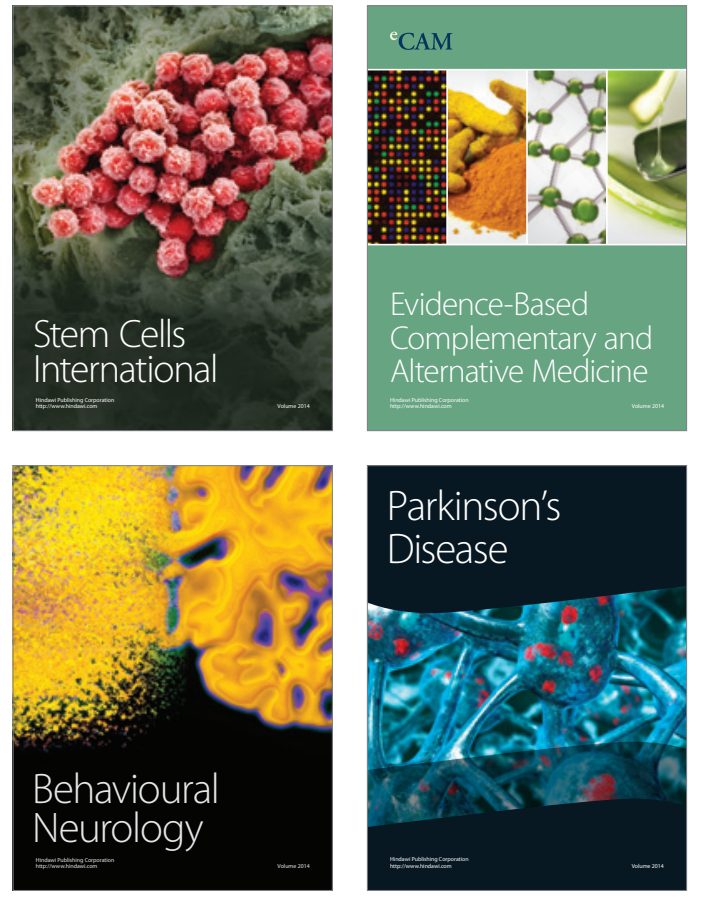
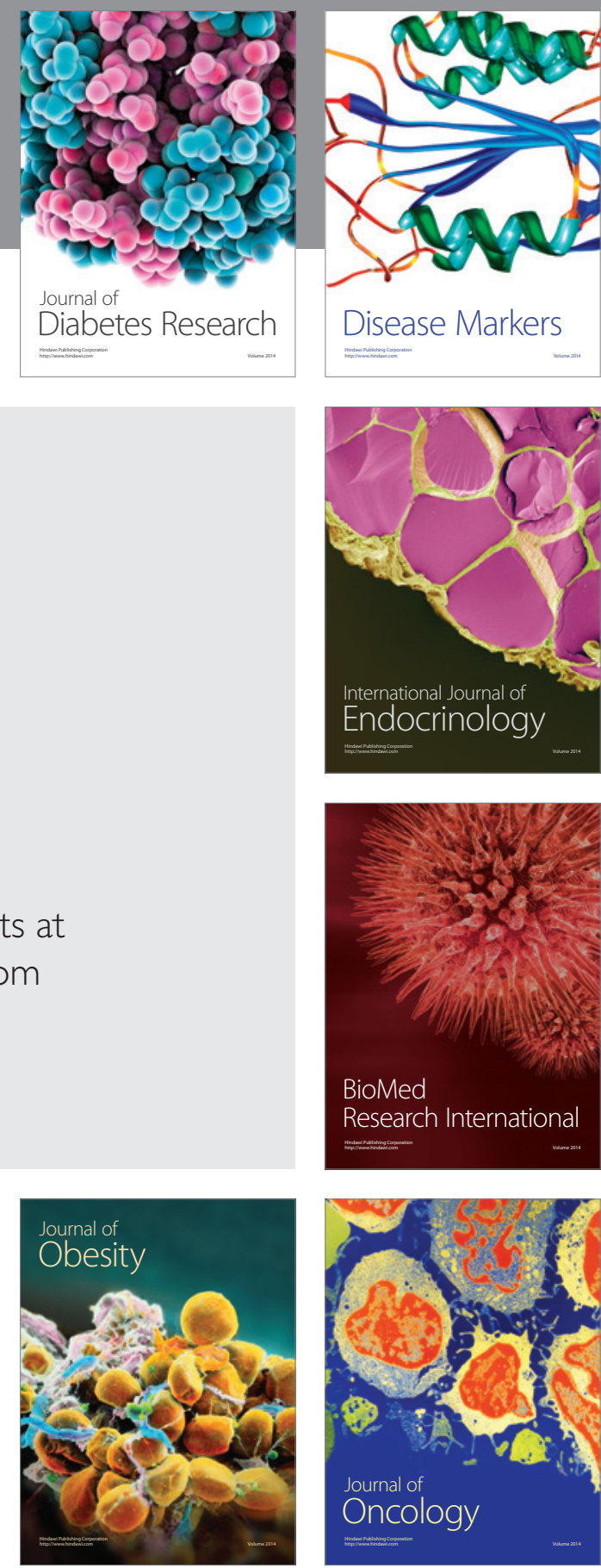

Disease Markers
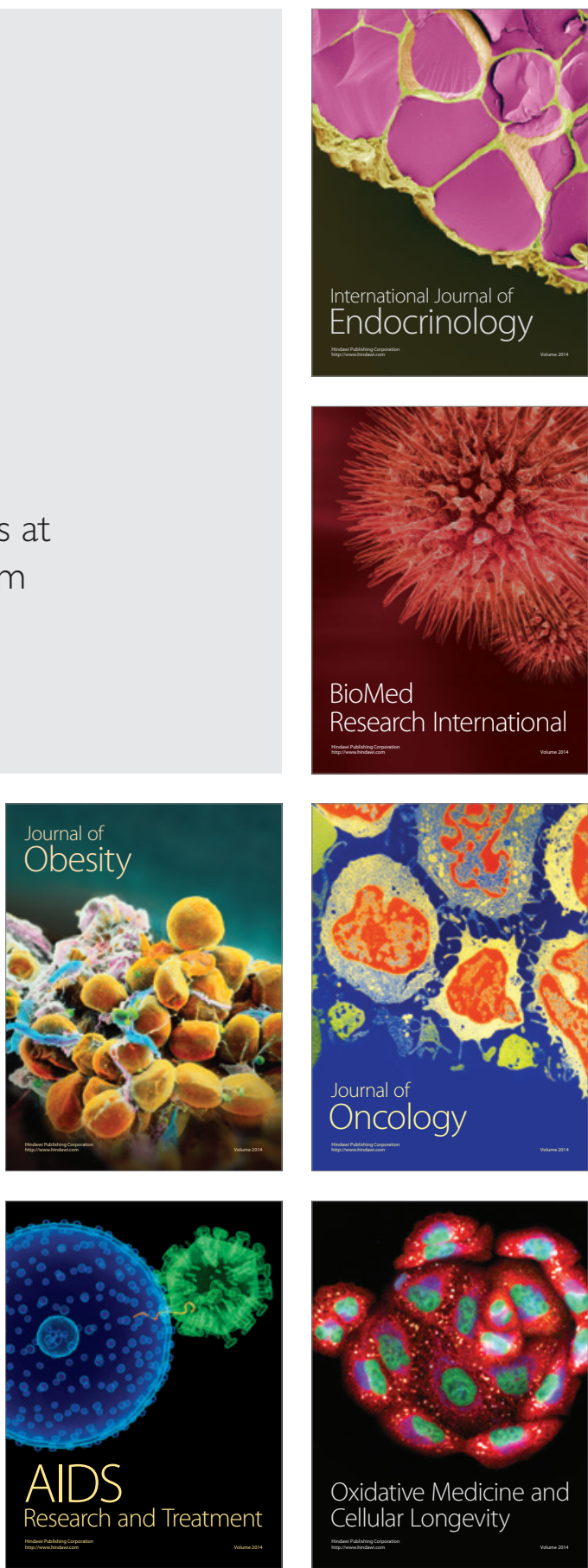